\title{
ALGUNS FUNGOS DO BRASIL (PHYCOMYCETOS)
}

(Com 4 figuras no texto e 22 eslampas)

\author{
A. P. Viégas \\ A. R. Teixeira
}

\section{Chytridiales PLASMODIOPHORACEA}

Dos representantes desta família, apenas o gênero Plasmodiophora foi coletado em terras brasileiras, e, mesmo neste caso, deveria ter sido importado. Spongospora aparece mais frequentemente em lotes de tubérculos de batatinha vindos do estrangeiro. Pouco diremos a respeito. dêsses dois gêneros.

\section{PLASMODIOPHORA BRASSICE WOR.}

Êste é o organismo responsável pela hérnia da couve, moléstia bastante cosmopolita, admiràvelmente trabalhada por Woronin (16), em S. Petersburgo, Rússia.

O fungo penetra nas raízes da couve (e de outras crucíferas), sob. a forma de plasmódio. Invadindo êsses órgãos, através dos pêlos absorventes, ou mesmo a epiderme, desenvolve-se e, em dado momento, ocupa todo o lúmen da célula atacada. Segundo Woronin (16) e outros pesquisadores, Chupp (2), Kunkel (7), o plasmódio emigra da célula afetada para as células vizinhas.

Reagindo às substâncias produzidas pelo plasmódio, as células se hipertrofiam. Dividem-se ativamente. $O$ resultado final é o aparecimento de tumores não só na raiz mestra como também nas rázes secundárias das plantas suscetíveis.

Após atingir certo desenvolvimento, o plasmódio se divide. Cada fragmento dá origem a um esporo. Diferindo das espécies de Synchytrium e gêneros afins, em Plasmodiophora o conjunto de esporos (sôro) não traz membrana geral, envolvente. As raízes atacadas apodrecem sob a terra. 
Os esporos livres germinam, dando origem a zoosporos. Estes são amebóides, isto é, nus. Trazem um flagelo na sua parte anterior. Os zoosporos nadam na água do solo e (post-fusão aos pares ? ou isoladamente) penetram em novas raízes.

O ciclo de vida do organismo, no que diz respeito à diferenciação sexual, fusão de gametas, não foi ainda estudado a contento.

535 ( $^{*}$ - $-O$ Material por nós examinado, em Brassica oleracea L. (couve-manteiga), foi coletado pelo sr. Raul Drumond Gonçalves, Horto Florestal da Cantareira, São Paulo, Est. S. Paulo, em 21 de novembro de 1934.

Neste material, inda novo, podem ser observados com facilidade os plasmódios enchendo o lúmen das células, bem como os sôros de esporos. Estes medem $1,6-2 \mu$ de diâmetro e são hialinos.

Que saibamos, esta foi a primeira constatação de Plasmodiophora brassicæ Wor., aquí no Brasil.

\section{SPONGOSPORA SUBTERRANEA (WALLR.) JOHNSON}

Cancros salientes, hiantes, de 4-7 mm de diâmetro, negros, pulverulentos, nos tubérculos.

Bolas de esporos intracelulares, de tamanho variável, irregulares (no geral, arredondadas ou elípticas), localizadas nos tecidos hipertrofiados corticais (Est. I, a), maciças (Est. I, b), apresentando aquí e ali, em sua superfície, cavas ou fendas mais ou menos profundas (Est. I, b). Esporos irregulares, lisos, fuscos (Est. I, c).

397 - Em tubérculos de Solanum tuberosum L. (batatinha), provenientes da Holanda, interceptados pelo Serviço de Vigilância Vegetal, por A. Bitancourt, São Paulo, Est. S. Paulo, 11 de janeiro de 1933.

Nota : - Spongospora sublerranea (Wallr.) Johnson não ocorre entre nós, mas aparece freqùentemente em partidas de tubérculos importados para sementes.

\section{OIPIDIACEA}

\section{PSEUDOIIIDIOPSIS ACHLYA N. SP.}

Esporângios no geral esféricos ou elípticos (Est. II, $a, e$ ), às vêzes afetando formas várias (Est. II, f), localizando-se quer no interior das hifas, quer nos esporângios de $A c h l y a$ sp. (ver n. ${ }^{\circ}$ 3086) lisos, de parede delicada, protoplasma homogêneo, hialino, granuloso ao amadurecer, que se fragmenta em pedaços para dar origem aos zoosporângios, os

(*) Estes números referem-se a materiais (por vêzes lâminas, culturas, fotografias, fotomicrografias, chapas para projeção, desenhos, etc.) depositados junto ao herbário do Instituto Agronômico, Campinas, Est. S. Paulo. 
quais ganham o exterior por um ou mais tubos que rompem as paredes das hifas. Tubos de descarga 8-28 $\mu$ de comprimento, 3-6 $\mu$ de diâmetro (Est. II, a-g). Esporângios 20-70 x 16-60 $\mu$.

Zoosporângios 4-8 $\mu$ de diâmetro, post-descarga esféricos, permanecendo quiescentes à extremidade do tubo. Quando em movimento ativo, pois são monoplanéticos, em forma de rim, providos de 2 flagelos na depressão hilar.

Oogônios esféricos, de parede lisa, de $2 \mu$ de espessura, hialina, 40-44 $\mu$ de diâmetro (Est. II, h, i), de conteúdo granuloso post-fecundação. Exibem centrosfera grande circundada de periplasma homogêneo, de granulação delicada, antes da fecundação (Est. II, h). Post-fecur. dação, o protoplasma adquire aparência revôlta, grosseira (Est. II, i).

Células companheiras (anterídio) 20-30 $\mu$ de diâmetro, de paredes lisas, delicadas, globosas ou elípticas (Est. II, i), subtendendo cada uma apenas um oogônio.

Germinação dos oosporos não vimos.

3072 - Sôbre hifas, esporângios, etc., de Achlya sp., encontrados com muita frequência de junho a agôsto em culturas feitas em moscas (Musa domestica L.), a partir de água ou terra de tanques ao derredor de Campinas, Est. S. Paulo. Fotos e desenhos feitos em 24 de agôsto de 1939, no laboratório de Botânica, do Instituto Agronômico.

Sporangiis 20-70 x 16-60 $\mu$, sphaericis vel ellipticis, raro cylindraceis, intramatricalíbus, laevibus; praeditis parietibus hyalinis delicatissimis.

Protoplasma granulosum, ad maturitatem in fragmenta evolutum ex quibus zoospo. rangia emergunt.

Exit-tubis cylindraceis vel conicis, $8-28 \times 6 \%$.

Zoosporangiis primo globosis, ad extremitatem tubulorum quiescentibus, hyalinis, 4-8 $\mu$ diam.; biflagellatis quum motus dant.

Oogonia sunt 40-44 $\mu$ diam., sphaerica, laevia, globosa, achroa, parietibus $2 \mu$ crassis ; antheridiis tum globosis, tum ellipticis, $20-30 \mu$ diam., hyalinis, laevibus, pro guoque oogonio singulis.

3072 - Parasitica in hyphis sporangiisque, etc., Achlyæ sp., lab. botanico, I.A., Campinas, Prov. St. Pauli, Brasiliae, Amer. Austr., jun. - aug., 1939.

\section{RHIZIDIACERE}

\section{$R H I Z O P H I D I U M \mathrm{SP}$.}

Micẻlio intramatrical, muito delicado, hialino, de conteúdo granuloso, ramificando-se irregularmente, diminuindo gradativamente de diâmetro para as extremidades (Est. III. a).

Esporângios globosos, hialinos, extra-matricais, de parede delicada, lisa, 7-9 $\mu$ de diâmetro, desprovidos de papila, com bulbos subesporan- 
giais diminutos, germinando por esporos nadadores uniflagelados, de $1-1 / 2 ; \mu$ de diâmetro (Est. III, d).

Oosporos extramatricais, monospóricos, $5-6 \mu$ de diâmetro, de paredes lisas.

3050 - Sôbre filamentos de Spirogyra sp., leg. A. P. Viégas, de culturas obtidas a partir de terra proveniente de lago existente em frente à faz. Monte D'Este, estrada Campinas a Mogí-Mirim, Campinas, Est. S. Paulo, 10 de agôsto de 1939.

Nota: - Anterídios não pudemos observar em nosso material. A espécie se carateriza pelo diminuto tamanho dos cistos subesporangiais.

\section{CLADOCHYTRIACEAE \\ PHYSODERMA HYDROCOTYLIDIS N. SP.}

Sôros na maioria epífilos (Est. IV, a), pardo-avermelhados, bulados, recobertos pela epiderme, 1-1,5 mm de diâmetro, isolados, raro confluentes, à maturidade imperceptíveis quase, no centro de lesões amareladas irregulares, depois necróticas.

Micélio delicadíssimo, ramificado, inter- ou intracelular, mais treqùente nos bordos das lesões. Nas porções mais velhas é evanescente. Esporângios globosos, mais freqùentes no tecido lacunoso (Est. IV, b, c), comprimidos lateralmente, pardos, lisos, 12-21 x 10-20 $\mu$, providos de um opérculo lateral e grande gota de substância oleosa na parte central (Est. IV, d). Protoplasma granuloso e hialino separa a gota da parede do esporo (Est. IV, c, d). Esporos nadadores (Est. IV, e) uniflagelados, 3-4 $\mu$ de diâmetro, piriformes ou um tanto alongados quando em movimento ativo, depois, pela perda do flagelo, quiescentes, adquirindo então forma globosa (Est. IV, f) e parede hialina.

2561 (tipo) - Sôbre fôlhas vivas de Hydrocotyle reniformis Spreng., leg. A. P. Viégas, sede I.A., Campinas, Est. S. Paulo, 9 de novembro de 1938.

2637 - Sôbre Hydrocotyle reniformis Spreng., leg. A. P. Viégas, tina da estufa, sede I. A., Campinas, Est. S. Paulo, 19 de dezembro de 1941.

3578 - Sôbre Hydrocotyle reniformis Spreng., leg. H. P. Krug e O. Zagatto, estufa, sede I. A., Campinas, Est. S. Paulo, 10 de dezembro de 1940.

3914 - Sôbre Hydrocotyle reniformis Spreng., leg. O. Zagatto, barrica da estufa, sede I. A., Campinas, Est. S. Paulo, 21 de julho de 1941.

Maculis nullis vel flabidulis, postremo necroticis, irregularibus, amphigenis. Soris rufo-brunneis, epiphyllis, bullatis, 1.1,5 mm diam. Mycelium delicatissimum, hyalinum, evanescens. Sporangiis globosis, lateraliter compressis, laevibus, intracellularibus, 12-21 x $10-20 \mu$, operculo circulari praeditis. Zoosponiis pyriformibus, uniflagellatis, $3-4 \mu$ diam., deinde gliobosis, guiescentibus, pariete hyalina instructis. 
In foliis vivis Hydrocotylis reniformis Spreng., leg. A. P. Viegas, sede I.A., Campinas, Prov. St. Pauli, Brasiliae, Amer. Austr., nov. 9, 1938.

Nota : - Por variadas vêzes tentamos observar a germinação dos esporângios, mas não conseguimos. Empregamos soluções açucaradas, variações de temperatura, etc., mas em tôdas as nossas tentativas os resultados foram improfícuos. Por isso, não sabemos o método de descarga, o número de zoosporos produzidos, em média, em cada esporângio. Observação de esporos nadadores foi feita uma só vez e, recentemente, em material do qual se retirou, com agulha, massa de esporângios, montando-se em água e examinando-os a seguir sob o micróscopio. Assim se puderam observar esporos nadadores, flagelo, seus movimentos. Também, sôros de várias idades foram fixados em Craf, incluidos em parafina, cortados ao micrótomo rotativo. Os cortes, foram coloridos pela hematoxilina. Este corante $e ́$ absorvido com alta intensidade e firmeza pela substância oleosa da gota central. Dificilmente pode ser removido. Por essa razão, os fenômenos nucleares não puderam ser:"estudados, como tencionávamos, a-pesar do grande número de lâminas'preparadas. Experiências de inoculação foram realizadas na estufa, onde temos

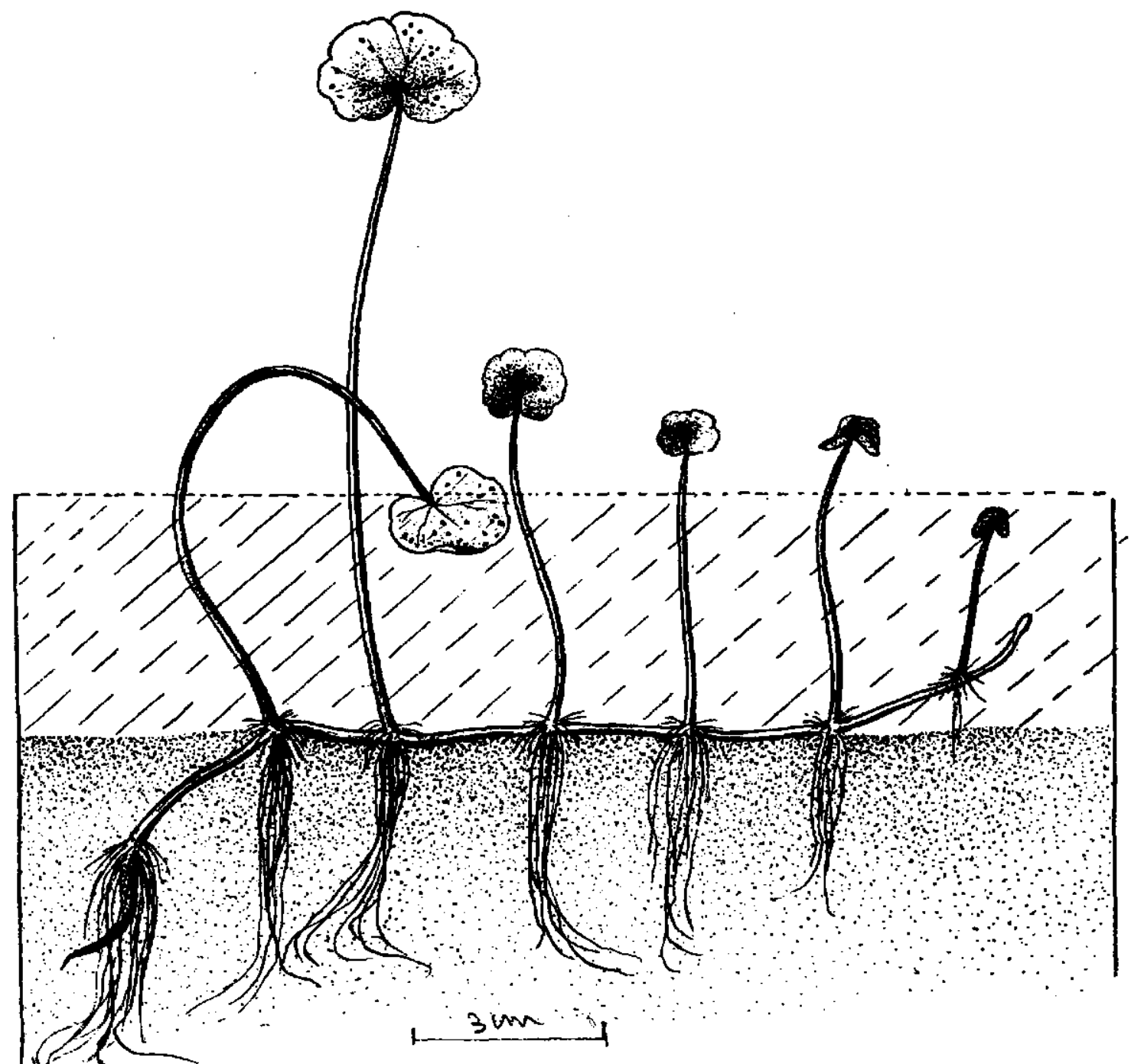

Fig. 1 
preservado o organismo por vários anos. Em tinas contendo Hydrocotyle sadios, basta colocar na água que os banha umas tantas fôlhas com sôros maduros, para se obterem, após algum tempo, novas fôlhas atacadas. Como se sabe, as fôlhas novas de H.|reniformis irrompem dos nos dos ramos sob a água (Fig. 1), dobradas de modo típico. Enquanto imersas, é que se dá a inoculação. Quando as fôlhas emergem, os sôros amadurecem. As fôlhas velhas, exibindo descoloração pronunciada da substância verde ao derredor dos sôros, tombam no líquido; é então quando os esporângios libertam os zoosporos. Estes nadariam e se fixariam às fôlhas novas inda submersas, repetindo o ciclo.

Nada podemos adiantar acêrca da sexualidade do organismo, porquanto o mecanismo importante, abertura dos esporângios, não pudemos reproduzí. lo à vontade, em laboratório.

Synchylrium bonaerense Speg., foi descrito por Spegazzini (12) ,em follhas vivas de (Hydrocotyle bonderense Lam). H. Umbellata L. coletadas perto do Parque Palermo, em Buenos Aires, Rep. Argentina. Todavia, os esporângios são esféricos, medindo 50-70: de diâmetro (11).

\section{PHYSODERMA ZEE-MAYDIS SHAW.}

Sôros pardo-ferrugíneos, nas células parenquimatosas da baínha das fôlhas e das palhas, etc., alongadas, confluentes (Est. V, a).

Esporângios globosos intracelulares (Est. V, b), comprimidos lateralmente, pardo-amarelados, de parede espêssa de 2-3 $\mu$, conteúdo granuloso, gutulado. Esporângios providos de um opérculo (Est. V, c), que, à maturidade, se abre. Medem os esporângios 24-28 x 18-20 $\mu$.

548, 550 - Sôbre Zea mays L. (milho), leg. A. S. Costa, sede I. A., Campinas, Est. S. Paulo, 21 de janeiro de 1935.

\section{Saprolegniales}

\section{SAPROLEGNIACEAE}

ACHLYA SP.

Colônia em forma de cabəleira branca, gelatinosa, alcançando $6 \mathrm{~mm}$ de raio, em tôrno de frutos, moscas, usados como isca (Est. VI, a).

Hifas bastante desenvolvidas, não muito ramificadas, dirigidas em direção radial, 18-20 $\mu$ de diâmetro. Em culturas idosas, as hifas tendem a produzir gemas (Est. VII, b) globosas ou piriformes, de 50-60 $\mu$ de diâmetro, 70-90 $\mu$ de comprimento, de protoplasma granuloso, lisas.

Esporângios clavulados (Est. VII, c), numerosos, afilados para o ápice, 500-1000 $\mu$ de comprimento, 36-40 $\mu$ de diâmetro, à maturidade opacos, brancos como leite quando examinados sob a lupa, germinando 
por esporângiosporos que se reúnem em bola na extremidade distal (Est. VII, d). Esporangiosporos 9-10 $\mu$ de diâmetro (Est. VII, d).

Sob condições anormais, os esporangiosporos germinam in situ, isto é, dentro do próprio esporângio (Est. VII, e, f).

Depois de permanecerem certo tempo na extremidade do esporângio, os zoosporos emergem, como estruturas reniformes, providos de 2 flagelos, na depressão hilar (Est. VII, g). Depois de se movimentar por certo tempo, entram em quiescência; perdem os flagelos, adquirem forma globosa, ao mesmo tempo que se revestem de delicada membrana. Germinam, a seguir, por meio de tubo delicado, de 1,5-2.0 $\mu$ de diâmetro (Est. VII, h).

Oogônios piriformes, amarelados, lisos, apicais, nunca intercalares, 40-60 × 50-75 $\mu$ (Est. VII, i). Anterídios diclinos, ramificados, com a porção fértil (gametângio) de $20 \times 8 \mu$ na média (Est. VII, i). Tubos de fertilização não foram constatados.

Oosporos globosos, lisos, um tanto excêntricos, 45-50 $\mu$ de diâmetro, um em cada oogônio (Est. VI, j).

3086 - Cultivado e observado com frequência em frutos de Vitis sicyoides Mig. e em corpos esterilizados de Musca domestica L. por A. P. Viégas, lab. de Botânica, I. A., a partir de terra e água provenientes de tanques dos arredores de Campinas, Est. S. Paulo, junho de 1939.

3772 - Sôbre Musca domestica L. (mosca), leg. A. P. Viégas, lab. de Fitopatologia, sede I. A., Campinas, Est. S. Paulo, 2 de junho de 1941.

\section{SAPROLEGNIA?}

Micélio branco, flocoso, ramificado, desenvolvendo-se abundantemente, primeiro nas guelras, depois em diversas partes do corpo do peixe. Hifas cilíndricas, septadas, tortuosas, hialinas ou com levíssima tonalidade amarelada, de $4-8 \mu$ de diâmetro (Fig. 2, a), ramificando-se irregularmente, desenvolvendo, em culturas, apressórios clavuladoglobosos, 8-10 x 15-20 $\mu$. Esporângios não vimos nem em cultura nem em guelras atacadas que se recobrem de crescimento branco do organismo.

Paredes das hifas espêssas, gelatinosas. Conteúdo homogêneo, com granulações um tanto grosseiras. Falsos septos mais ou menos freqùentes. Clamidosporos intercalares, globoso-elípticos, lisos, de conteúdo protoplásmico denso, mais granuloso e grosseiro que o das hifas (Fig. 2, b).

4036 - Parasítico, de modo epidêmico, a peixes, leg. A. P. Viégas, lab. de Fitopatologia, sede I. A., Campinas, Est. S. Paulo, 12 de agôsto de 1942 . 


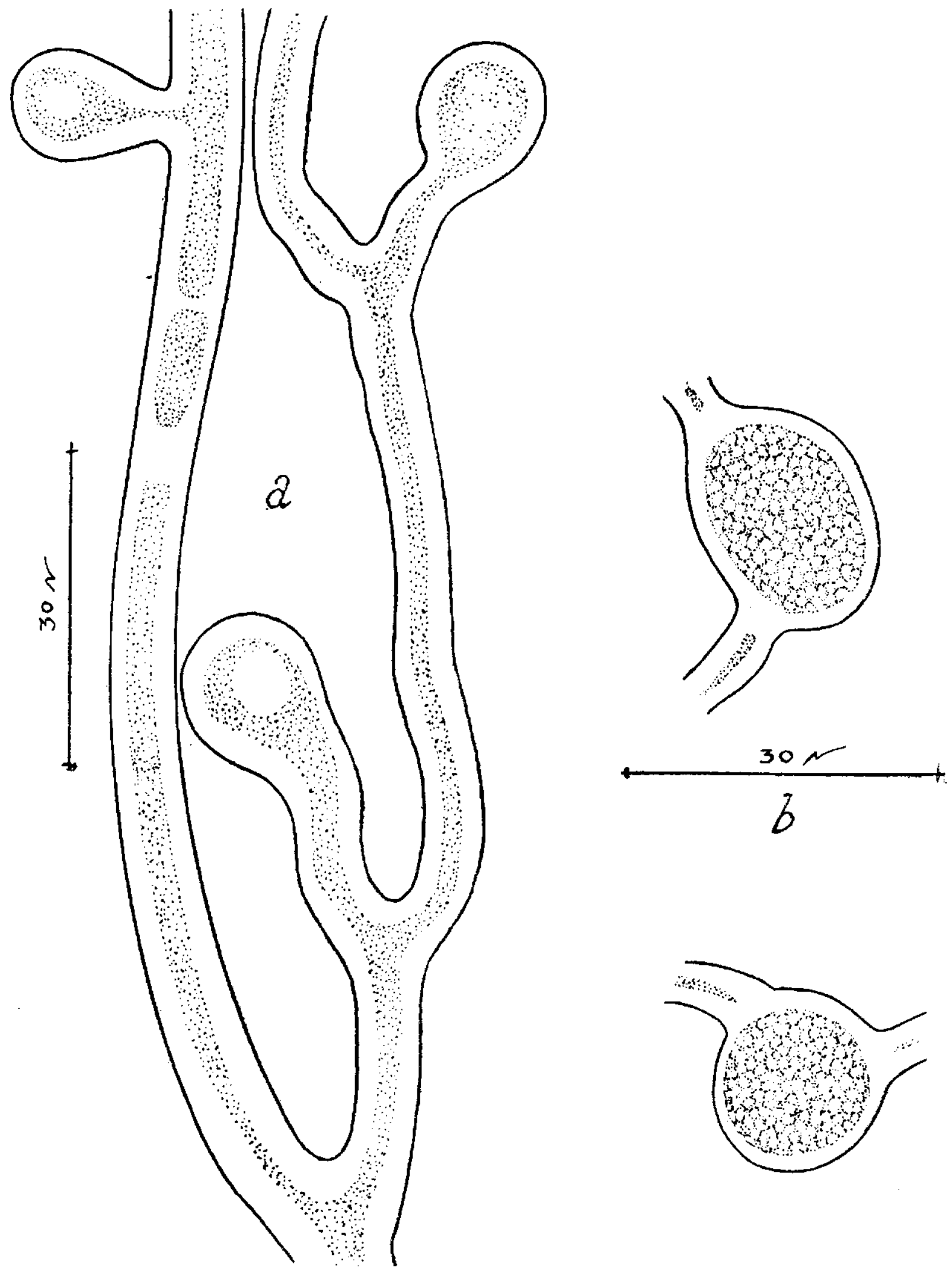

Fig. 2 
Nota : - Usando guarús coletados em um pequeno córrego, cuidamos de reproduzir epidemias artificialmente em laboratório. No fundo de frascos, colocámos areia de rio e algumas plantas oxigenantes. A seguir, enchemo-los com água e nêles colocámos os peixes em 3 lotes:

a) Levou como inóculo um peixe morto, portador de micélio;

b) Levou culturas do organismo;

c) Serviu de controle.

Em nenhum dêles, após 10 dias, apareceu a moléstia. Verificamos também que os peixes, deixados à míngua, comiam não só o corpo do peixe morto, que fôra lançado em a, como também micélio do fungo que puséramos em $\mathbf{b}$. Já havíamos dado por terminada essa nossa experiência, quando recebemos um lote de peixes vermelhos, aparentemente vitimados pela mesma moléstia. Um dêstes, bastante atacado, mas ainda vivo, foi deitado no frasco $b$, e retirado horas depois, no mesmo dia, assim que morreu. No dia seguinte, todos os guarús dêsse frasco b, amanheceram mortos.

Antes de morrer, os peixes atacados freqùentemente vinham à tona da água, pois, o fungo, invadindo as guelras, impede a respiração normal. Assim que morrem, sôbre êsses órgãos aparece o crescimento branco de hifas.

\section{Peronosporales ALBUGINACEA}

\section{ALBUGO BLITI (BIV.) KUNTZE}

Sôros hipófilos, salientes, isolados ou confluentes, brancos, recobertos pela epiderme, depois pulverulentos, no geral de $1-2 \mathrm{~mm}$ de diâmetro. Conidióforos clavulados, hialinos, de parede espêssa na base, eretos, de 30-40 $\mu$ de alto, $12-15 \mu$ de diâmetro.

Conídias em cadeias, globosas, lisas, pela pressão poliédricas, $16-20 \times 14-16 \mu$.

112 - Sôbre fôlhas de Amaranthus sp. (carurú), leg. A. P. Viégas, faz. Sta. Elisa, I. A., Campinas, Est. S. Paulo, 19 de abril de 1933.

Nota : - Oosporos ausentes.

114 - Sôbre Amaranthus sp. (carurú), leg. A. S. Costa, Esc. Sup. Agric. "Luiz de Queiroz", Piracicaba, Est. S. Paulo, 5 de dezembro de 1933.

2623 - Sôbre Amaranthus sp. (carurú), leg. G. P. Viégas, sede I. A., Campinas, Est. S. Paulo, 30 de novembro de 1938.

3740 - Sôbre Amaranthus sp. (carurú branco), leg. dr. Luiz Torres de Oliveira, rua Cel. Quirino, próximo ao Tenis Slube, Campinas, Est. S. Paulo, 26 de março de 1941.

\section{ALBUGO BRASILIENSIS (SPEG.) P. HENN.}

Sôros brancos, na maioria hirófilos, grupados, recobertos pela epiderme, depois pulverulentos, de $1 \mathrm{~mm}$ de diâmetro. 
Conidióforos hialinos, de parede espêssa, percorridos por um canal central que se dilata no ápice, numa célula basal, 25-28 × 12-13 $\mu$.

Conídias em cadeias, lisas, globosas, hialinas, medindo 16-20 $\mu$.

1089 - Sôbre fôlhas de Ageratum conyzoides L. (mastruço), leg. A. S. Costa, Juquiá, Est. S. Paulo, 31 de agôsto de 1935.

1932 - Sôbre Ageratum conyzoides L. (mastruço), leg. A. P. Viégas, Av. Brasil, Campinas, Est. S. Paulo, 6 de janeiro de 1942.

2756 - Sôbre Ageratum conyzoides L. (mastruço), leg. A. R. Teixeira, rua Prefeito Passos, Campinas, Est. S. Paulo, 5 de março de 1942.

3677 - Sôbre Ageratum conyzoides L. (mastruço), leg. Josué Deslandes, Correntes, Est. de Pernambuco, outubro de 1939.

Nota: - Deslandes n ${ }^{\circ} .95$.

3679 - Sôbre Ageratum conyzoides L. (mastruço), leg. Josué Deslandes, Correntes, Est. de Pernambuco, outubro de 1939.

Nota: - Deslandes $n^{\circ} .421$.

3761 - Sôbre fôlhas de Ageratum conyzoides L. (mastruço), leg. A. P. Viégas, mato, Águas de Prata, Est. S. Paulo, 30 de abril de 1941.

4173 - Sôbre Ageratum conyzoides L. (mastruço), leg. A. P. Viégas: e Melo Barreto, Parque Jardim, Belo-Horizonte, Est. de Minas Gerais, 19 de janeiro de 1943.

\section{ALBUGO CANDIDA (PERS. EX LÉV.) O. KUNTZE}

Sôros hipófilos, brancos, de início recobertos pela epiderme, depois pulverulentos, isolados ou em grupos, de $0,5-1 \mathrm{~mm}$ de diâmetro, brilhantes, às vêzes confluentes.

Micélio intercelular, raro septado, hialino, provido de haustórios globosos de 3-4 ie de diâmetro.

Conidióforos hialinos, de parede espessada na porção basal, 32-40. x $12-14 \mu$.

Conídias globosas, hialinas, lisas, poliédricas devido à pressão mútua, $12-20 \times 12-16 \mu$, dispostas em cadeias.

Oosporos ausentes.

67 - Sôbre Raphanus sativus L. (rabanete), leg. A. P. Viégas, Fonte Sônia, Valinhos, Est. S. Paulo, 1.0 de abril de 1933.

816 - Sôbre Brassica alba Rabenh. (mostarda), leg. A. S. Costa, horta, sede I. A., Campinas, Est. S. Paulo, 1. de julho de 1935.

2584 - Sôbre Raphanus sativus L. (rabanete), leg. A. S. Costa e A. Vetorato, Est. Exp. de Ribəirão Preto, Ribeirão Preto, Est. S. Paulo, 16 de novembro de 1938. 
4195 - Sôbre fôlhas de Raphanus sativus L. (rabanete), leg. Acácio Nogueira, rua Barão de Atibaia n. ${ }^{\circ}$ 600, Campinas, Est. S. Paulo, 25 de maio de 1943.

\section{ALBUGO IPOMOEA PANDURANA (SCHW.) SWINGLE}

Sôros brancos nas fôlhas, na maioria hipófilos, de $1 / 2-1 \mathrm{~mm}$ de diâmetro, salientes, isolados ou em grande número, às vêzes cobrindo porções extensas, especialmente nos brotos novos. Nos ramos e pecíolos, - fungo ocorre produzindo deformações notáveis.

Conídias em cadeias, 14-18 x 13-14 , globosas, ou cilíndricoglobosas pela pressão, lisas. Micélio intercelular.

Oosporos ausentes.

8 - Sôbre Ipomcea purpurea Lam. (curriola), Av. Barão de Itapura, Campinas, Est. S. Paulo, leg. A. P. Viégas, 6 de março de 1933.

Nota : - A espécie é bastante comum, atacando Convovulacex.

151 - Sôbre Ipomcea sp., leg. A. S. Costa e J. C. Marmo, Escola Sup. Agric. "Luiz de Queiroz", Piracicaba, Est. S. Paulo, 7 de novembro. de 1933.

414 - Sôbre Ipomcea batatas Lam. (batata doce), leg. O. Zagatto, sede I. A., Campinas, Est. S. Paulo, 8 de março de 1934.

1400 - Sôbre Ipomæa batatas Lam., var. 22 (batata doce), Secção de Raízes e Tubérculos, leg. A. S. Costa, sede I. A., Campinas, Est. S. Paulo, 27 de janeiro de 1936.

3221 - Sôbre Ipomoea batatas Lam. (batata doce), leg. J. F. da Cunha, Est. Exp. de Ubatuba, Ubatuba, Est. S. Paulo, 30 de setembro de 1939.

3331 - Sôbre Ipomoa sp., leg. J. Kiehl, rua S. José, Piracicaba, Est. S. Paulo, 20 de março de 1940.

3332 - Sôbre Ipomæa batatas Lam., var. napoleão (batata doce), leg. Olavo Boock, Est. Exp. de Tietê, Tietê, Est. S. Paulo, 8 de abril de 1940.

ALBUGO PLATENSTS (SPEG.) SW.

Sin. Cystopus platensis Speg. Rev. Arg. Hist. Nat. 1: 1-12. 1891.

Sôros hipófilos, brancos, recobertos pela epiderme, depois pulverulentos, de 0,5-1 mm de diâmetro (Fig. 3, a).

Conidióforos clavulados, hialinos, lisos, de parede espessada na base, $36-40 \times 12-15 \mu$.

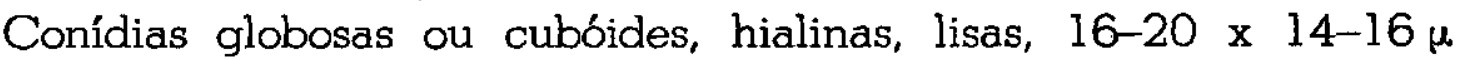
(Fig. 3, b). Ooscoros ausentes. 


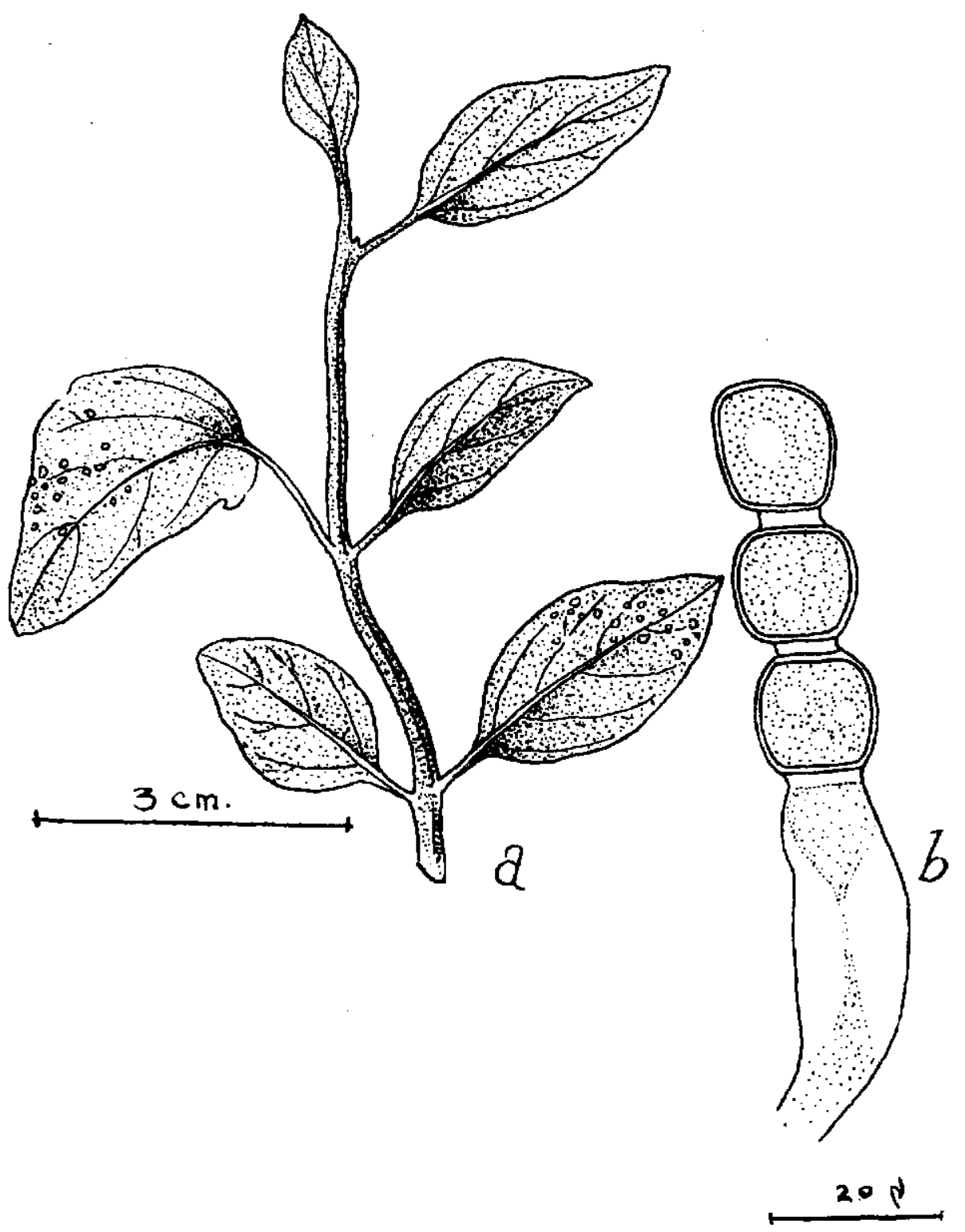

Fig. 3

458 - Sôbre fôlhas de Borhavia hirsuta L. (herva tostão) leg. A. P. Viégas e H. P. Krug, faz. do sr. Tito de Lemos, Arraial dos Sousas, Campinas, Est. S. Paulo, 6 de março de 1934.

\section{ALBUGO PORTULAC.E (DC.) KUNTZE}

Sôros brancos, brilhantes, pulvinados, à maturidade pulverulentos, 1-5 $\mathrm{mm}$ de diâmetro, em grupos ou isolados, na maioria hipófilos.

Conidióforos clavulados, de parede espêssa $(4 \mu), 56-60 \times 12 \mu$; células puffer, hialinas, de paredes delicadíssimas, $4 \mu$ de altura, gelatinizando cedo. Conídias globosas, pela pressão mútua, poliédricas, hialinas, lisas, $12-18 \times 10-14 \mu$, em cadeias. 
19 - Sôbre fôlhas de Portulaca oleracea L. (beldroega), leg. A. P. Viégas, faz. Sta. Elisa, I. A., Campinas, Est. S. Paulo, 16 de março de 1933.

3912 - Sôbre Portulaca oleracea L. (beldroega), leg. O. Zagatto, sede I. A., Campinas, Est. S. Paulo, 30 de abril de 1942.

ALBUGO TRAGOPOGONIS (DC.) S. F. GRAY

Sôros hipófilos, brancos, bulados, isolados ou em grupos, de 0,5 $\mathrm{mm}$ de diâmetro. Conidióforos clavulados, hialinos, espessados de $4 \mu$ na base, lisos, 12-14 x 32-36 $\mu$.

Conídias globoso-deprimidas, hialinas, com 2 cicatrizes polares nítidas, $15-20 \times 16-20 \mu$, paredes delicadas, lisas.

2719 - Sôbre fôlhas de Jaegeria hirta (Lag.) Less., leg. A. S. Costa e Ismar Ramos, Alto da Serra, Ubatuba, Est. S. Paulo, 23 de novembro de 1938.

3020 - Sôbre Jaegeria hirta (Lag.) Less., leg. A.: P. Viégas, Alto da Serra, Aguatuba, Ubatuba, Est. S. Paulo, 13 de março de 1939.

\section{PYTHIACEA}

\section{PHYTOPHTHORA CITROPHTHORA (SM. A SM.) LEONIAN}

40 - Sôbre Citrus aurantifolia Swingle (limão galego), leg. A. P. Viégas, rua do Rosário n. ${ }^{\circ}$ 184, Piracicaba, Est. S. Paulo, 19 de março de 1933.

256 - Sôbre Citrus sinensis Osbeck (laranjeira), leg. A. P. Viégas, Chácara Orosimbo Maia, Campinas, Est. S. Paulo, 7 de agôsto de 1933.

2116 - Sôbre Citrus sp., leg. J. F. Lima, pomar do sr. João Mó, Piracicaba, Est. S. Paulo, 12 de maio de 1937.

Nota : - O organismo foi isolado de Citrus sinensis Osbeck, var. baianinha (laran. jeira), e inoculado em limões Eureka, por A. S. Costa.

\section{PHYTOPHTHORA GONAPODIOIDES (PETERSEN) BUISMAN}

Micélio hialino, sôbre o substrato ondulado ou sinuoso, de $4 \mu$ de diâmetro. Dêle partem ramos mais ou menos retos, verticais, às vêzes providos de um ou dois septos transversais, ramos êsses simples, raro ramificados, que atingem 100-200 $\mu$ de comprimento,'e que dão origem a um esporângio apical. Os esporângios são em forma de limão, hialinos e, post-descarga de seus zoosporângios, podem produzir novo esporângio no interior do esporângio vazio (Est. VIII, $a, b$ ). O processo pode-se repetir duas ou mais vêzes, de tal modo que é freqùente encon- 
trarem-se paredes de espcrângios envolvendo um esporângio central de formação mais recente (Est. VIII, c, d, e). O micélio a seguir pode continuar seu desenvolvimento para repetir a formação de esporângios um pouco mais à frente.

Os esporângios medem, na média, 36-40 x 26-28 $\mu$, e são portadores de uma papila mais clara na sua extremidade distal. São lisos, de parede delicada. Conteúdo homogêneo.

Anterídeos e oogônios não foram constatados em nosso material.

A espécie parece ocorrer com freqùência entre nós.

3073 - O material por nós observado, obtivemo-lo em culturas em laboratório, em 24 de agôsto de 1939, sede I. A., Campinas, Est. S. Paulo, provenientes de ramos verdes imersos em água.

Nota : - Sôbre esta espécie, consultar: $(1,4,6,9)$.

\section{PHYTOPHTHORA INFEST ANS (MONT.) DE BARY}

Lesões necróticas irregulares, encharcadas, largas, de bordo amarelado na página superior (Est. IX), esbranquiçado na página inferior pelo crescimento abundante de conidióforos do fungo. $O$ tecido invadido apodrece com rapidez e facilidade extremas.

Conidióforos ramificados, levemente coloridos de pardo, lisos, sem septos, atingindo cêrca de 300-350 $\mu$ de comprimento, 6-8 $\mu$ de diâmetro na sua parte média. Os conidióforos se afilam gradativamente em direção à parte distal, ao mesmo tempo que apresentam, de espaço a espaço, dilatações mais ou menos cônicas, típicas (Est. $X, a)$ da espécie.

Conídias piriformes (Est. X, b), apiculadas, da mesma côr que os conidióforos, curto-pediceladas, lisas, 24-28 x 16-18 $\mu$, com pedicelo $2 \mu$ de comprimento.

126 - Sôbre Solanum tuberosum L. var. argentina (batatinha), leg. H. P. Krug e A. P. Viégas, Campo Largo, Est. S. Paulo, 12 de abril de 1933.

117 - Sôbre Solanum tuberosum L. var. ouro (batatinha), leg. J. B. Castro, Cascata, Est. S. Paulo, 19 de abril de 1933.

125 - Sôbre Solanum tuberosum L. var. gelkaragis (batatinha), leg. A. S. Mueler, Esc. Agr. de Viçosa, Viçosa, Est. Minas Gerais, 3 de janeiro de 1935.

1252 - Sôbre Solanum tuberosum L. (batatinha), leg. A. S. Costa, faz. S. Pedro da Cascata, Itatiba, Est. S. Paulo, 28 de outubro de 1935.

1276 - Sôbre fôlhas de Solanum tuberosum L., var. erdgold (batatinha), leg. A. S. Costa, Fst. Exp. de Sorocaba, Sorocaba, Est. S. Paulo, 30 de outubro de 1935. 
1357 - Sôbre Solanum tuberosum L., var. argentina (batatinha), leg. A. S. Costa, sítio Brejão, S. José do Rio Pardo, Est. S. Paulo, 5 de dezembro de 1935.

1364 - Sôbre Solanum tuberosum L., var. argentina (batatinha), leg. A. S. Costa, sítio Boa Vista, S. José do Rio Pardo, Est. S. Paulo, 5 de dezembro de 1935.

1498 - Sôbre Solanum tuberosum L., (batatinha), leg. A. S. Costa, Cascata, Est. S. Paulo, 15 de abril de 1936.

2975 - Sôbre Solanum tuberosum L., var. sterling (batatinha), leg. A. P. Viégas, Monjulo, Cunha, Est. S. Paulo, 6 de março de 1939.

4094 - Sôbre fôlhas de Solanum tuberosum L. (batatinha), leg. Manuel Sproesso, faz. Boa Vista, Monte-Mor, Est. S. Paulo, 10 de abril de 1942.

\section{PYTHIUM DEBARYANUM HESSE}

Micélio hialino, não septado, ramificado, gutulado, de paredes delicadas, intercelular (Est. XI, a), variando de 2 a $7 \mu$ de diâmetro.

Em cultura, o fungo cresce ràpidamente, cobrindo a superfície de

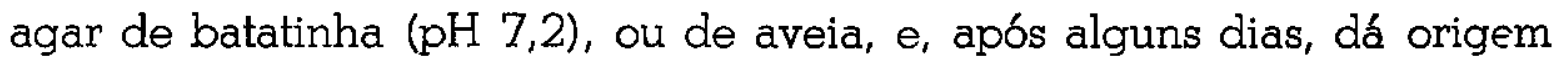

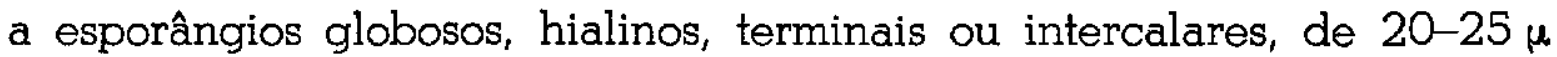
de diâmetro (Est. XI, b).

Clamidosporos globosos, de parede lisa, delicada, hialinos, intercalares, isolados ou em grupos, não distintos dos esporângios em tamanho (Est. XII, c).

Oogônios globosos, semelhantes aos esporângios, terminais, originando-se de dilatações clavuladas do micélio, de 12-34 $\mu$ de diâmetro (média de cem, 17,65 $\mu$ ) ricos de substância oleosa, lisos. Anterídeos clavulados, hialinos, laterais, provenientes do próprio ramo que deu origem ao oogônio ou vindo da hifa diferente, de início túrgido e postdescarga flácido, imperceptível quase (Est. XII, d; Est. XIII, e).

Oosporos globosos, lisos, de parede espêssa, hialina, $12-20 \mu$ de diâmetro (Est. XIII, f).

$O$ organismo cresce com facilidade e rapidez nos meios comuns de cultura. Cresce também em maçãs maduras, rabanetes, cenouras e beterrabas, ocasionando-lhes podridão mole típica. Quando inoculado em tubérculos de batatinha, produz sempre uma podridão aquosa, sem cheiro. Os tubérculos ficam como que encharcados, mantendo o córtex intacto. Quando tubérculos, afetados pela podridão, são cortados, a porção necrosada se oxida, tomando coloração rósea, e depois parda (Est. XIII, g). 
476 - Sôbre tubérculos de Solanum tuberosum L. (batatinha), leg. Ludovico Bonato, antigo depósito de batatas, sede I. A., Campinas, Est. S. Paulo, 1.० de agôsto de 1933.

Nota : - A moléstia afeta tubérculos novos, que foram machucados durante o arrancamento.

1975 -- Sôbre Solanum tuberosum L. var. Kathadin (batatinha), leg. A. S. Costa, faz. Santa Elisa, I. A., Campinas, Est. S. Paulo, 12 de janeiro de 1937.

1235 - Sôbre frutos de Myrciaria jaboticaba (Vell.) Berg. (jaboticabeira), leg. A. S. Costa, faz. Santa Elisa, I. A., Campinas, Est. S. Paulo, 16 de outubro de 1935.

\section{BREMIA LACTUCA REGEL}

Lesões, de início pequenas, amareladas, mais tarde pardas, grandes, atingindo larga área dos tecidos foliares (Est. XIV, a), às vêzes de contornos geométricos. Conidióforos hipófilos, brancos, formando emaranhados frouxos, erectos, ramificados. Os ramos mais da extremidade se dilatam em discos providos de esterigmas. Cada esterigma subtende uma conídia (Est. XIV, b). Conídias globosas ou elípticas, hialinas, lisas, $20 \times 16-18 \mu$ (Est. XIV, c). Oosporos ausentes.

25 - Sôbre fôlhas de Lactuca sativa L. (alface), leg. José ICanuto Mármore, horta da Esc. Sup. Agric. "Luiz de Queiroz", Piracicaba, Est. S. Paulo, 23 de agôsto de 1933.

104 - Sôbre Lactuca sativa L. (alface), leg. H. P. Krug, Esc. Sup. Agric. "Luiz de Queiroz", Piracicaba, Est. S. Paulo, 24 de agôsto de 1933.

119 - Sôbre fôlhas de Lactuca sativa L. (alface), leg. H. P. Krug, Esc. Sup. Ágric. "Luiz de Queiroz", Piracicaba, Est. S. Paulo, 24 de agôsto de 1933.

\section{PERONOPLASMOPARA CUBENSIS (B. e C.) CLINTON}

Lesões largas, de bordos geométricos, coalescentes, amarelas, na superfície da fôlha, depois necróticas, pardas, limitadas pelas nervuras. Correspondendo a essas descolorações, na face inferior se observam crescimentos pardacentos, vilosos (mildew) do organismo, (Est. XV, a).

Conidióforos nascendo em número de 3-4 por feixe, através das aberturas estomatais (Est. XV, b), longos, cilíndricos, ramificando-se na parte distal livre, de modo monopodial, terminando em ramos afilados na extremidade, ramos êsses portadores de conídias.

Conídias elipsóides ou em forma de limão, de coloração escura, papiladas, de paredes ligeiramente pontilhadas, 28-32 × 24-25 $\mu$ (Est. $X V, b, c)$. 
75 - Sôbre fôlhas de Cucurbita sp., leg. J. Hermann, sede I. A., Campinas, Est. S. Paulo, 3 de abril de 1933.

76 - Sôbre Cucumis melo L. (melão), leg. A. P. Viégas, Horto Florestal da Cantareira, S. Paulo, Est. S. Paulo, 30 de Abril de 1933

1506 - Sôbre Cucurtitaceæ (chuchú selvagem, machucho), leg. A. S. Costa, Presidente Prudente, Est. S. Paulo, 22 de abril de 1936.

\section{PERONOSPORA EFFUSA (GREW) RABH.}

Lesc̃es irregulares, primeiro gecmétricas e amareladas, mas depois pardas, irregulares, abrangendo largas áreas das fôlhas (Est. XVI, a).

Conidióforos hipófilos, hialinos, ramificando-se dicotômicamente, terminando em esterigmas recurvos de 5-18 $\mu$. de comprimento, afilados. Atingem os conidióforos cêrca cie 240-300 $\mu$ de alto, e têm, na base, 7-8 $\mu$ de diâmetro (Est. XVI, b).

Conídias ovóides, lisas, pardo-claras, providas de pedicelo curto na parte kasal, carecerdo de apículo, 18-30 x 17-22 $\mu$ (Est. XVI, c).

569 - Sôbre fôlhas de Chenopodium hircinum Schrad. (caperiçoba), leg. H. P. Krug e A. S. Costa, sede I. A., Campinas, Est. S. Paulo, 8 de março de 1935.

\section{PERONOSPORA PARASITICA (PERS.) DE BARY:}

Crescimento branco, abrangendo grandes áreas da página inferior das fôlhas.

Conidióforos cilíndricos $2 \mathrm{CO}-3 \mathrm{CO} \mu$ de ccmprimento, 11-12 $\mu$ na base, ramificando-se dicotĉmicômente e terminando por esterigmas afilados, recurvos, fortadores de conídias (Est. XVII, a).

Ccnídias elíptico-glckceas, fuscas, sєm rapila, lisas, 20-23×24-26 $\mu$ destacando-se $\mathrm{ccm}$ facilidade (Est. XVII, b).

Oosporos ausentes.

609 - Sôbre fôlhas de Brassica oleracea L. (couve), leg. A. S. Costa, horta I. A., Campinas, Est. S. Paulo, 28 de abril de 1935.

700 - Sôbre fôlhas de Brassica oleracea L., var. capitata (repolho) leg. A. S. Costa e O. Zagatto, fáz. Augusto Stefen, Monte-Mor, Est. S. Paulo, 6 de junho de 1935.

2074 - Sĉbre Brassica sp. (couve brócoli), leg. A. S. Costa, Est. Exp. de Citricultura, Cōmpiras, Est. S. Paulo, 19 de maio de 1937. 


\section{PLASMOPARA HALSTEDII (FARL.) BERL. e DE TONI}

Lesões anfígenas, atingindo freqùentemente até $1 \mathrm{~cm}$ de comprimento, geométricas, isto é, limitadas pelas nervuras, amarelo-pardas na página inferior (Est. XVIII, a).

Conidióforos ramificados, cilíndricos, hialinos, 320-400 $\mu$ de comprimento, 8-10 $\mu$ de diâmetro, emergindo em tufos através das aberturas estomatais (Est. XVIII, b). Ramos secundários nascendo perpendicularmente aos primários, terminando mais ou menos bruscamente em esterigmas cilíndricos de $7-8 \mu$ de comprimento, $1,5-2 \mu$ de diâmetro. Conídias elíptico-cilíndricas, lisas, hialinas, não apiculadas, curtíssimopediceladas, 14-20 × 11-14 $\mu$ (Est. XVIII, c).

1441 - Sôbre fôlhas de Compositæ, leg. H. P. Krug, Est. Exp. de Pindorama, Pindorama, Est. S. Paulo, 17 de dezembro de 1935.

2751 - Sôbre fôlhas de Ageratum conyzoides L. (mastruço), leg. A. S. Costa e A. R. de Lima, Est. Exp. de Tietê, Tietê, Est. S. Paulo, 9 de fevereiro de 1939.

3251 - Sôbre Ageratum conyzoider L. (mastruço), leg. A. P. Viégas, faz. Santa Elisa, I. A., Campinas, Est. S. Paulo, 18 de fevereiro de 1940.

\section{PLASMOPARA VITICOLA (B. e C.) BERL. A DE TONI}

Lesões interessando ambas as páginas das fôlhas, de início amareladas, mais tarde necróticas, pardas.

Sob a página inferior, correspondendo às áreas necrosadas da superfície, observa-se o crescimento branco, viloso, do fungo (Fig. 4, a). As lesões são isoladas. Crescem rápidas. Coalescem.

O micélio, depois de se desenvolver no interior dos tecidos da fôlha, ganha o exterior através dos estômatos, para dar origem aos conidióforos (Fig. 4, b). Estes são de 200-300 $\mu$ de comprimento, cilíndricos, sem septós e de $6 \mu$ de diâmetro, e se reunem em feixes erectos (Fig. 4, b).

Na extremidade livre, os conidióforos se ramificam de modo típico: os ramos secundários formam ângulos quase que retos entre si e com - eixo principal. Os ramos secundários dão origem a ramos menores, que, por sua vez, produzem curtos esgalhos portadores de esterigmas. Cada esterigma, longo mais ou menos de $4 \mu$, subtende uma conídia ou esporângio (Fig. 4, b). 

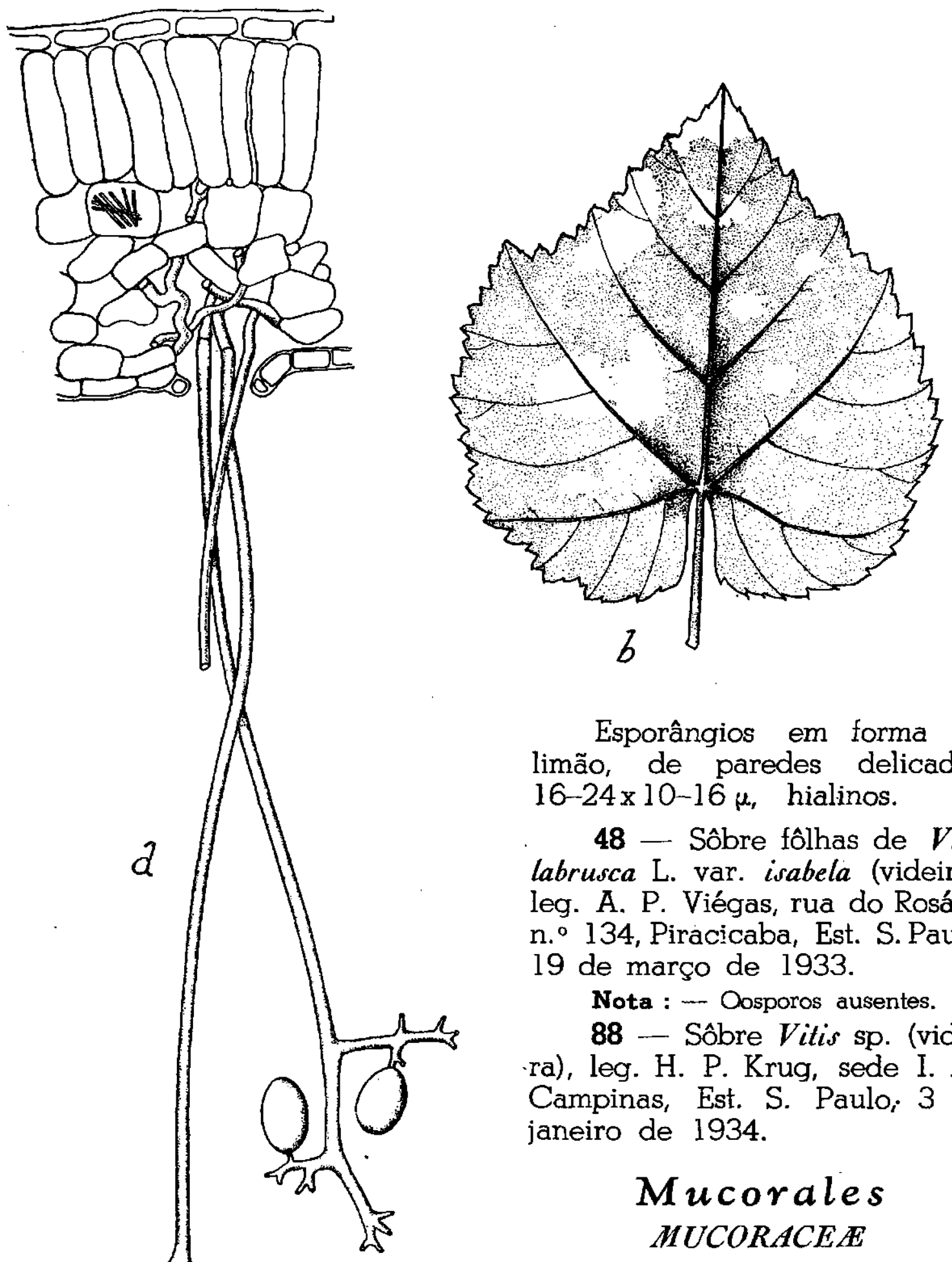

Esporângios em forma de limão, de paredes delicadas, 16-24x 10-16 $\mu$, hialinos.

48 - Sôbre fôlhas de Vitis labrusca L. var. isabela (videira), leg. A. P. Viégas, rua do Rosário n. ${ }^{\circ}$ 134, Piracicaba, Est. S. Paulo, 19 de março de 1933.

Nota : - Oosporos ausentes.

88 - Sôbre Vitis sp. (videira), leg. H. P. Krug, sede I. A., Campinas, Est. S. Paulo, 3 de janeiro de 1934.

\section{Mucorales MUCORACEA}

RHIZOPUS NIGRICANS EHRENB.

415 - Sôbre capulho de Gossypium hirsutum L. var. Texas big boll 7111-045 (algodoeiro), leg. O. Zagatto, sede I. A., Campinas, Est. S. Paulo, 2 de maio de 1934.

Fig. 4 
748 - Sôbre Ipomæa batatas Lam. (batata doce), leg. A. S. Costa, faz. Santa Elisa, I. A., Campinas, Est. S. Paulo, 25 de junho de 1935. 2103 - Sôbre frutos de Carica papaya L. (mamão), leg. Súlvio Moreira, Piracicaba, Est. S. Paulo, 11 de junho de 1937.

3049 - Sôbre frutos de Lycopersicon esculentum Mill. (tomateiro), leg. Otacílio F. de Sousa, faz. Santa Elisa, I. A., Campinas, Est. S. Paulo, 9 de agôsto de 1939.

3171 - Sôbre frutos de Prunus persica Sieb e Zucc. (pêssego), leg. F. C. Camargo, Est. Exp. de São Roque, São Rogue, Est. S. Paulo, 11 de dezembro de 1939.

3487 - Sôbre Ipomoea batatas Lam., var. las almas (batata doce), leg. A. P. Camargo, faz. Santa Elisa, I. A., Campinas, Est. S. Paulo, 1 de agôsto de 1940.

3490 - Sôbre raízes de Manihol utilissima Pohl var. tatú (mandioca), leg. Edgard S. Normanha, faz. Santa Elisa, I. A., Campinas, Est. S. Paulo, 1 de agôsto de 1940.

\section{PILOBOLACEA}

\section{PILOBOLUS LONGIPES VAN TIEGHEN}

Esporângios de início filiformes ou subulados (Est. XIX, a), apresentando na extremidade e aos lados numerosas gotas de exudato, à maturidade $2-3 \mathrm{~cm}$ de comprimento na média, podendo, sob certas circunstâncias, alcançar até 4-6 cm de altura. Trofocistos no geral externos, 1,5-2 mm x 400-500 $\mu$, ou apenas submersos, de côr amarela, sub-cilíndricos, lisos, providos de rizóides (Est. XIX, b), trazendo na parte basal uma célula mais ou menos triangular, də 15J-200 x 200-250 $\mu$ à qual segue. um rizóidə de 15-20 u de diâmətro, hialino na base e porção mediana, ligeiramente colorido junto à câmara sub-esporangial (ocelo).

Ocelo oval (Est. XIX, b), de 200-600 $\mu$ de diâmetro, 500-1000 $\mu$ de comprimento, de paredes dəlicadas como as do estipe, brancos. À maturidade amarelos.

Esporângios globoso-hemisféricos (Est. XIX, c), negros, de- $\frac{I}{4}-\frac{1}{2}$ mm de diâmətro; columəla cônica, amarelada.

Esporos (Est. XIX, d), de conteúdo amarelo, gutulados, lisos, 12-15 x 10-12 $\mu$, də paredəs espêssas də 1,5-2 $\mu$.

3838 - Sôbre excremento də Equus caballus L. (cavalo), leg. A. P. Viézas e A. R. Təixəira, estrəbaria dz. faz. Sazta Elisa, I. A., Campinas, Est. S. Paulo, 25 de agôsto de 1941. 
Nota : - A espécie carateriza-se pelo seu trofocisto horizontal, sub-cilíndrico, e pelos esporos arredondados.

Aquí em Campinas, a obtenção de esporângios desta espécie é muito fácil, especialmente nos meses de inverno.

Para isso, basta coletarmos excremento mais ou menos fresco, pô-lo em câmara úmida. Após 48 horas, os esporângios são produzidos em número considerável. Três dias depois, desaparecem, atacados por nemas e outros organismos.

Os esporangiosporos s6 germinam ap6s passarem pelo tubo digestivo do animal.

\section{PIPTOCEPHALID ACEA SYNCEPHALIS UBATUBENSIS N. SP.}

Micélio parasítico em fungo entomógeno desconhecido, de $8 \mu$ de diâmetro, pouco septado, de parede espêssa de $1 \mu$, incrustada de cristais diminutos. Conidióforos também de $8 \mu$ de diâmetro que se erguem do substrato apoiados em 3 ramos basais (Est. XX, a), 1-2 septados, incrustados, terminando numa bola de esporos de 60-70 $\mu$ de diâmetro. Columela clavulada (Est. XX, b), de 8-10 $\mu$ de diâmetro, hialina, de paredes mais delicadas; da columela partem métulas (Est. XX, c), hialinas, de 8-10 $\mu$ de comprimento e outro tanto de largo, as quais são portadoras de 8-9 esterigmas (Est. XX, c), clavulados, de 10-11 $\mu$ de longura $e$ 3-4 $\mu$ de diâmetro. Estes esterigmas são portadores de esporos hialinos, fusiformes, lisos, de 5-6 x 2-2,5 $\mu$ (Est. XX, d).

1019 - Sôbre fungo desconhecido atacando inseto desconhecido em fôlhas de Psidium guajava L. (goiabeira), leg. Felisberto de Camargo, Est. Exp. de Ubatuba, Ubatuba, Est. S. Paulo, 22 de agôsto de 1935.

Mycelio leviter colorato, incrustato, cum paucis septis, $8 \mu$ diam. Conidiophoris indivisis, raro septatis, 120-160 × $8 \mu$, columellam hyalinam, 8-10 $\mu$ 'diam. in apice exhibentibus: metulae complures, hyalinae, globosae 8-10 x 8-10 $\mu$; sterigmata 8-9, hyalina, clavulata 10-11 × 3-4 $\mu$; sporae hyalinae, fusoideae, laeviae, 5-6 × 2-2,5 $\mu$.

Parasitica fungi indeterminati in insecto ad folia Psidii guajave L., leg: Felisberto de Camargo, Est. Exp. de Ubatuba, Ubatuba, Prov. St. Pauli, Brasiliae, Amer. Austral, 22 Aug. 1935.

Typus sub n. ${ }^{\circ}$ 1019, in herb. I. A., Campinas, Prov. St. Pauli, Brasiliae.

\section{Entomophthorales}

\section{ENTOMOPHTHORACEA}

\section{$E M P U S A$ APHIDIS HOFFMANN}

Micélio hialino, raro septado, exceto no interior das coxas, tíbias dos insetos atacados, de 8-10 $\mu$ de diâmetro, altamente gutuladas (Est. $\mathrm{XXI}$, a). Conidióforos clavulados, digitados, mais frequentemente simples (Est. XXI, b), irrompendo através das junturas do tórax, abdómen e 
demais partes, dilatando-se no ápice em ocelo de 12-18 $\mu$ de diâmetro.

Conídias variáveis na forma, na maioria piriformes, $20-24 \times 12-13 \mu$, hialinas, lisas, freqùentemente apiculadas, $e$, quando recentemente projetadas, circundadas por um halo de substância gelatinosa (Est. XXI, c). Conídias secundárias menores que as primárias.

695 - Sôbre afídeos, em fôlhas de Solanum tuberosum L. (batatinha), leg. A. S. Costa, sede I. A., Campinas, Est. S. Paulo, 27 de maio de 1935.

3607 - Sôbre afídeos, em fôlhas de Solanum tuberosum L. (batatinha), leg. A. S. Costa, faz. Santa Elisa, I. A., Campinas, Est. S. Paulo, 16 de janeiro de 1941.

\section{EMPLSA DYSDERCI VIÉGAS}

2124 - Sôbre Dysdercus sp., leg. L. O. T. Mendes, sede I. A., Campinas, Est. S. Paulo, 8 de novembro de 1937.

Nota: - Sôbre esta espécie, consultar Viégas (15).

2385 - Parasita de Dysdercus ruficollis, leg. L. О. T. Mendes, Seç̧ão de Entomologia, sede I. A., Campinas, Est. S. Paulo, 21 de agôsto de 1938.

2562 - Sôbre Dysdercus mendesi, leg. A. P. Viégas, laboratório de Fitopatologia, sede I. A., Campinas, Est. S. Paulo, 28 de outubro de 1938.

2570 - Sôbre Dysdercus ruficollis (L.), leg. A. P. Viégas, laboratório de Fitopatologia, sede I. A., Campinas, Est. S. Paulo, 20 de outubro de 1938.

2751 - Sôbre Dysdercus sp., leg. A. P. Viégas, laboratório de Fitopatologia, sede I. A., Campinas, Est. S. Paulo, 7 de outubro de 1938.

2713 - Sôbre Dysdercus sp., leg. Paulo V. C. Bittencourt, Est. Exp. de Pindorama, Pindorama, Est. S. Paulo, 26 de dezembro de 1938.

\section{ENTOMOPHTHORA sp.}

Micélio hialino, cilíndrico, ramificado de $4-4,5 \mu$ de diâmetro, que, depois de se desenvolver no corpo do inseto, ganha o exterior, aí formando rizomorfos pardos (Est. XXII), longos, de milímetro ou mais. Tais cordões, por vêzes, lançam ramos aéreos.

2926 - Sôbre Tigaua seibæ Drake e Poot (Hem. - Tingitidæ), em fôlhas de Ceiba pentandra Gaertn (capoque), leg. Pedrito Silva, Est. Exp. Agua Preta, Est. Baía, 23 de abril de 1939. 


\section{LITERATURA CITADA}

1. Buisman, C. J. Roots rots caused by phycomycetes. Meded. Phytopath. Lab. "Willie Commelin Scholten" 11: 1-51, pl. 1-2. 1927.

2. Chupp, C. Studies on clubroot of cruciferous plants. Cornell Agr. Exp. St. Bul. 387: 421-452, fig. 95-110. 1917.

3. D'Utra, Gustavo. O problema da extinção dos gafanhotos. Bol. Secr. Agr., Ind. e Com. do Est. S. Paulo. Ser. 10: 1-15. 1910.

4. Fitzpatrick, H. M. Em The lower fungi. Phycomycetes, págs. 1-331. McGraw Hill Book Co. 1930.

5. Grove, W. B. A systematic account and arrangement of the Pilobolidae. Em A. H. Buller. Researches on fungi, vol. 6, pág. 190-224. Longmans Green \&.Co. 1934.

6. Kanouse, Bessie B. Physiology and morphology of Pythiomorpha gonapodioides. Bot. Gaz. 79: 196-206, pl. 1-13. 1925.

7. Kunkel, L. O. Tissue invasion by Plasmodiophora brassicæ. Jour. Agr. Res. 14: 543-572, pr. 61-80. 1918.

8. Moller, Alfred. Em Phycomyceten und Ascomyceten. Untersuchungen aus Brasilien, págs. 1-319, est. 1-11, Jena, Gustav Fischer. 1901.

9. Petersen, H. E. An account of Danish freshwater phycomycetes, with biologica and systematic remarks. Annales Mycologici 8: 494-560, fig. 1-27. 1910.

10. Rorer, J. B. A preliminary list of Trinidad fungi. Board of Agriculture Trinidad and Tobago Circ. 4: 37-44. 1911.

11. Saccardo, P. A. Em Sylloge fungorum 7: 293. 1888.

12. Spegazzini, C. Phycomycetae argentinae. Sep. Rev. Arg. Hist. Nat. 1: 1-12. 1891.

13. Spegazzini, C. Mycetes argentinenses. Anales del Museo Nacional de Buenos Aires 19: 257-458. 1909.

14. Thaxter, R. The Entomophthoreae of the United States. Mem. Bost. Soc. Nat. Hist. 4: 133-201, est. 14-21. 1888.

15. Vi6gas, A. P. Empusa dysderci n. sp., um novo parasita de Dysdercus. Jornal de Agronornia (Piracicaba) 2: 229-258, fig. 1-9. 1939.

16. Woronin, M. Plasmodiophora brassicx the cause of cabbage hernia. Phytopathological classics 4: 1-32. pr. 29-34. 1939. (Trad. por C. Chupp). 
Est. I
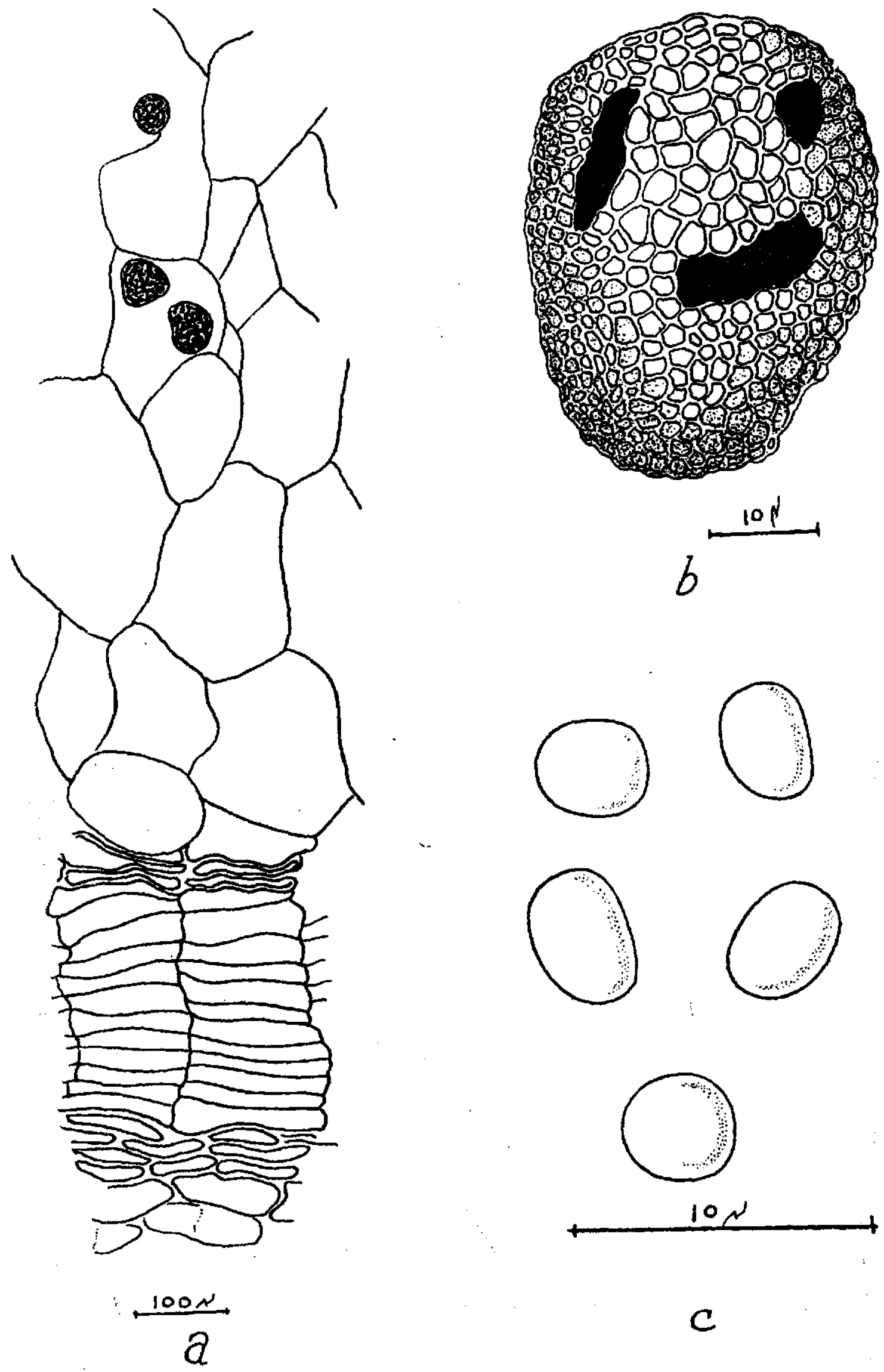

C 
Est. II
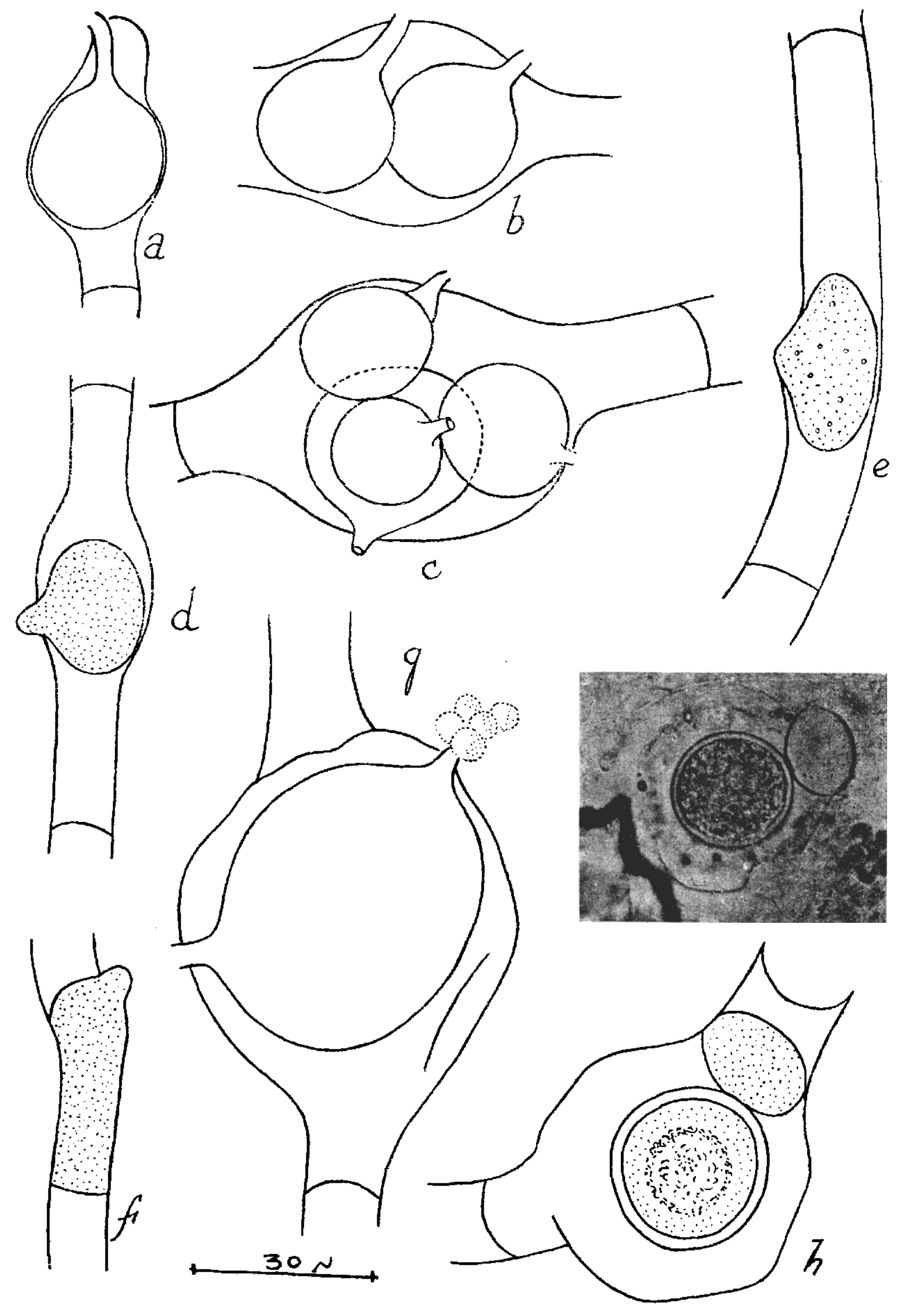
Est. III
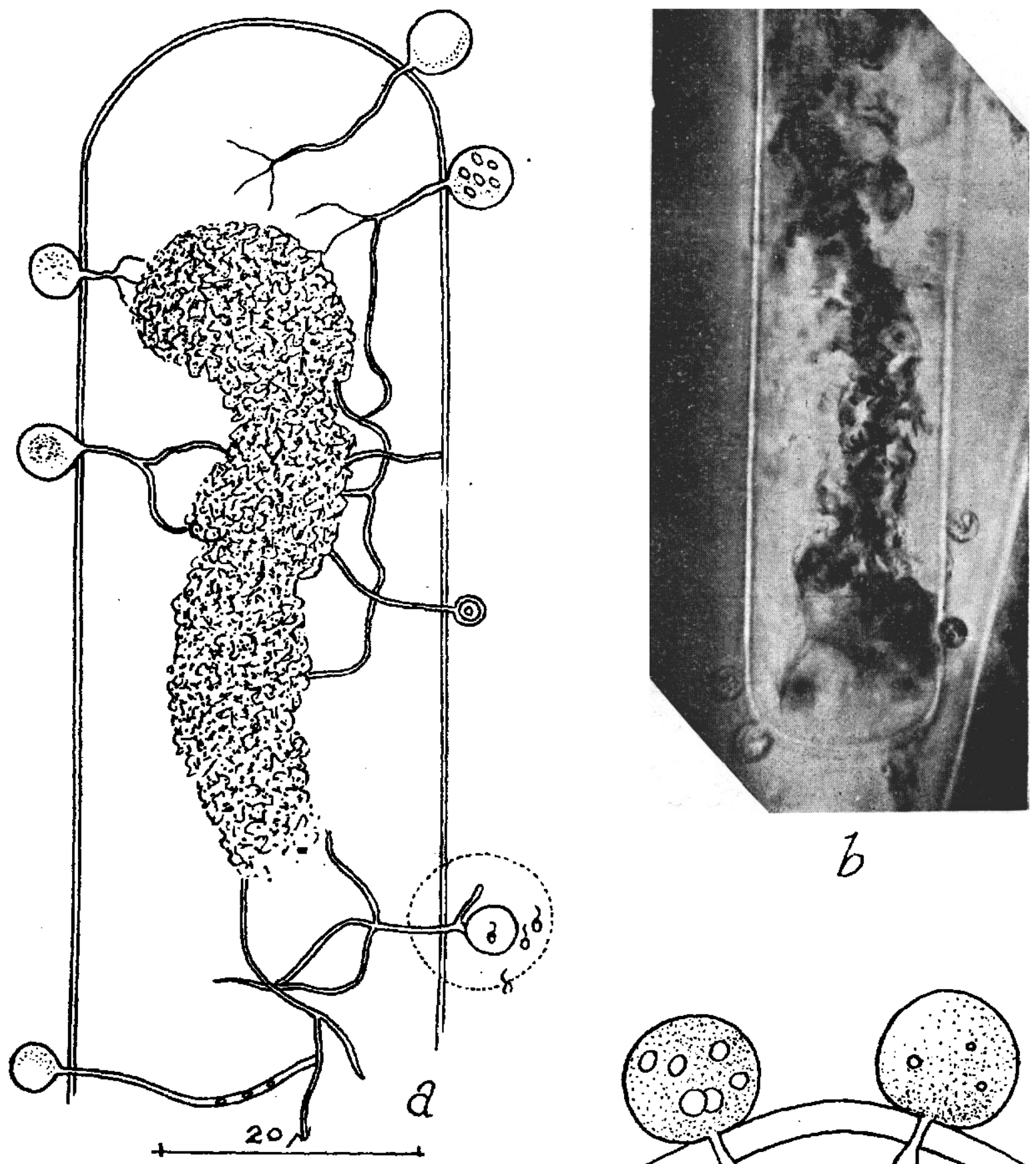

b
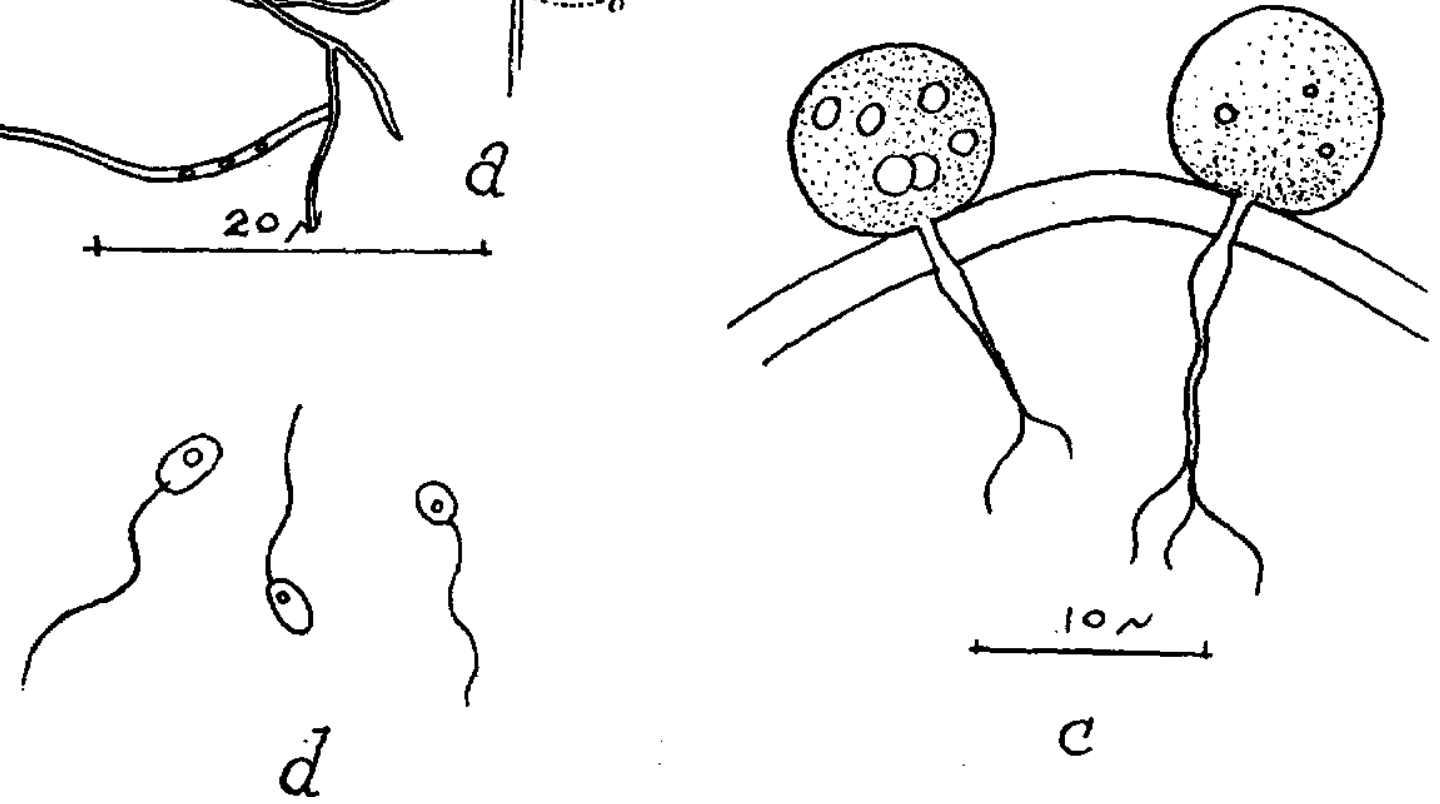

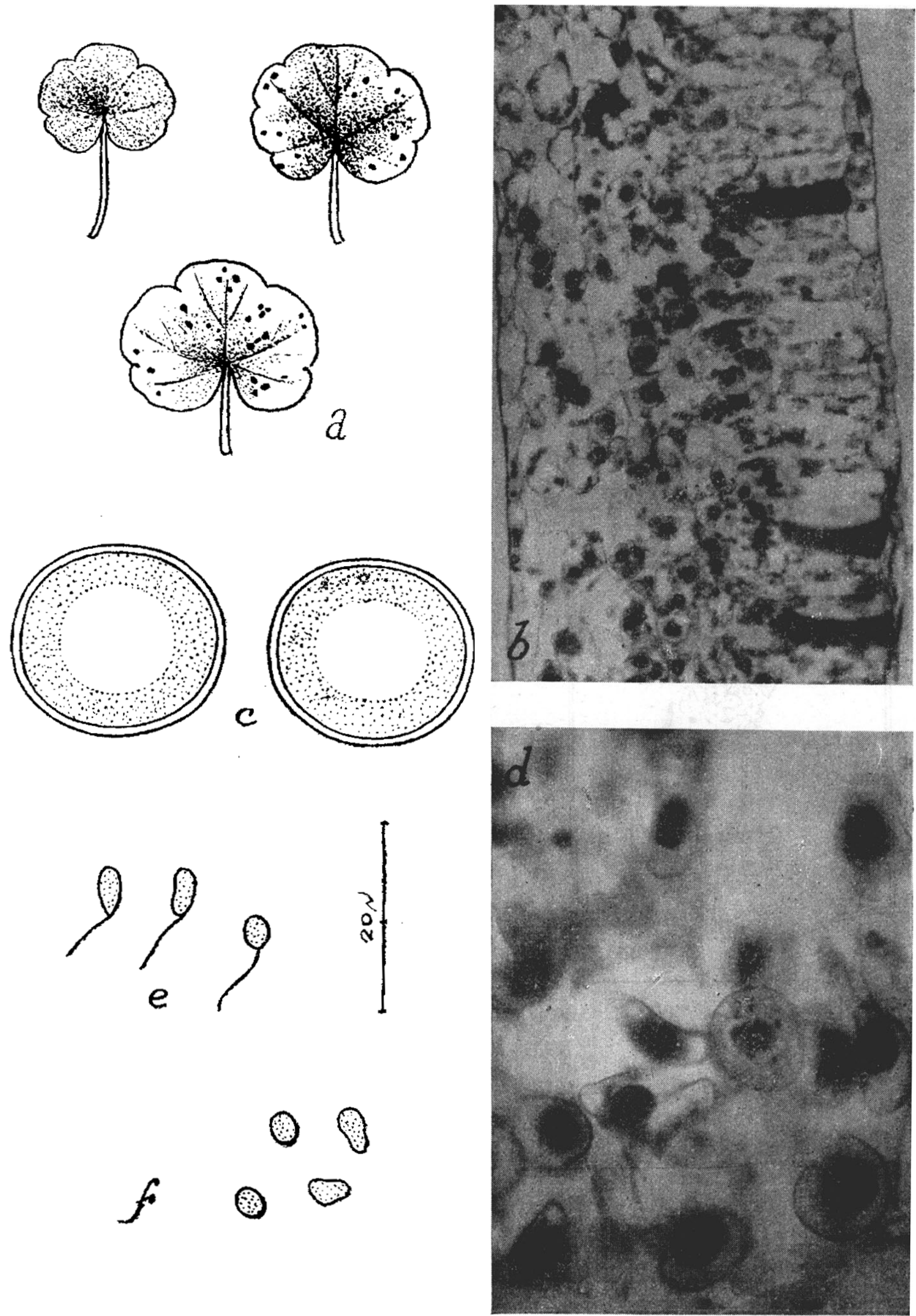
Est. V

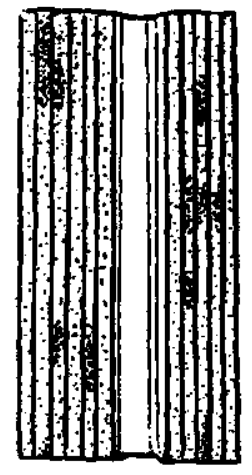

a

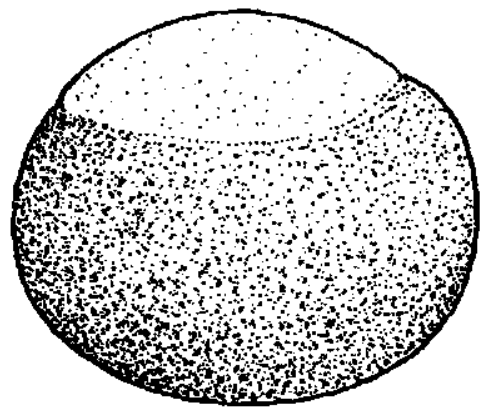

c
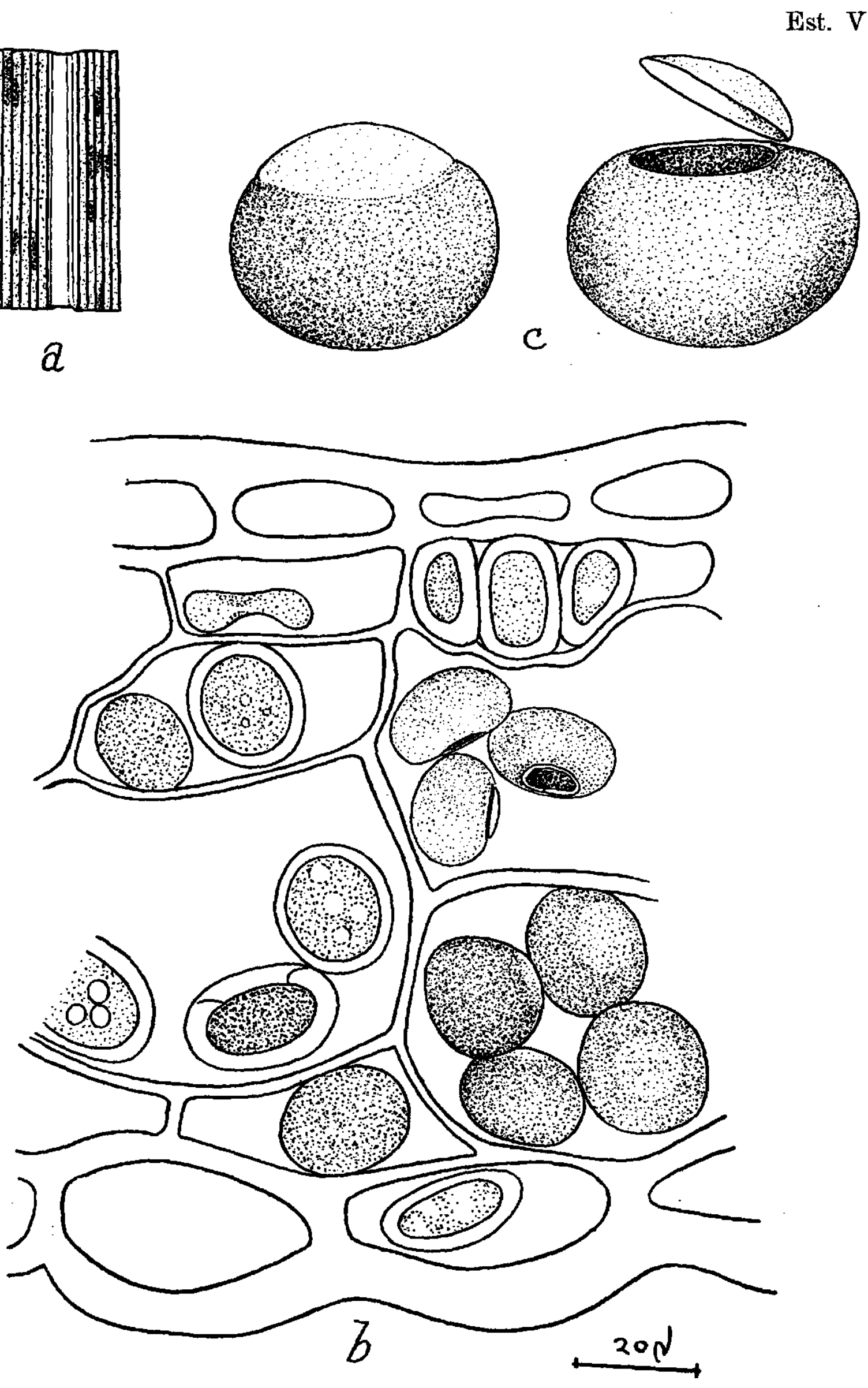


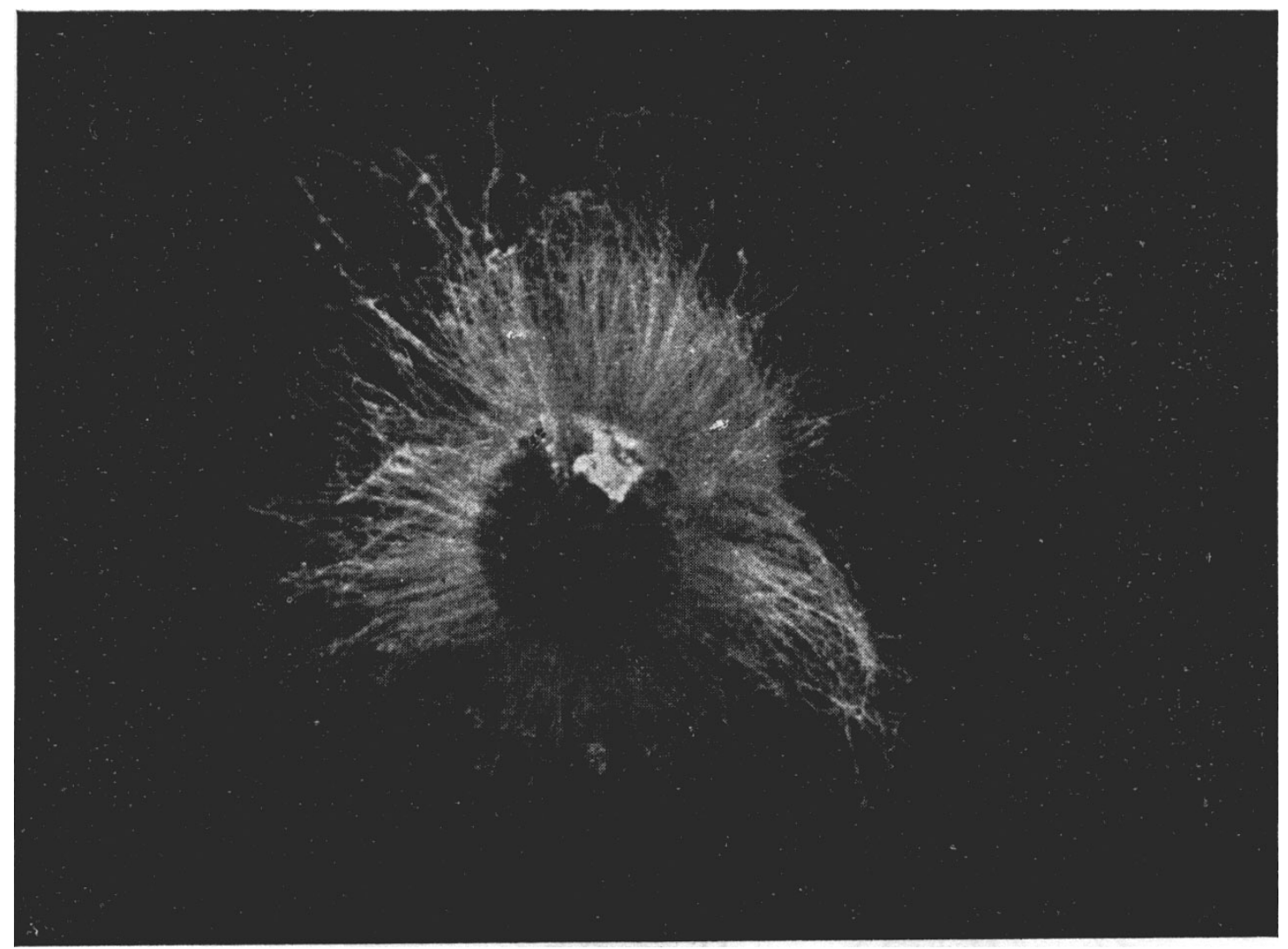

a
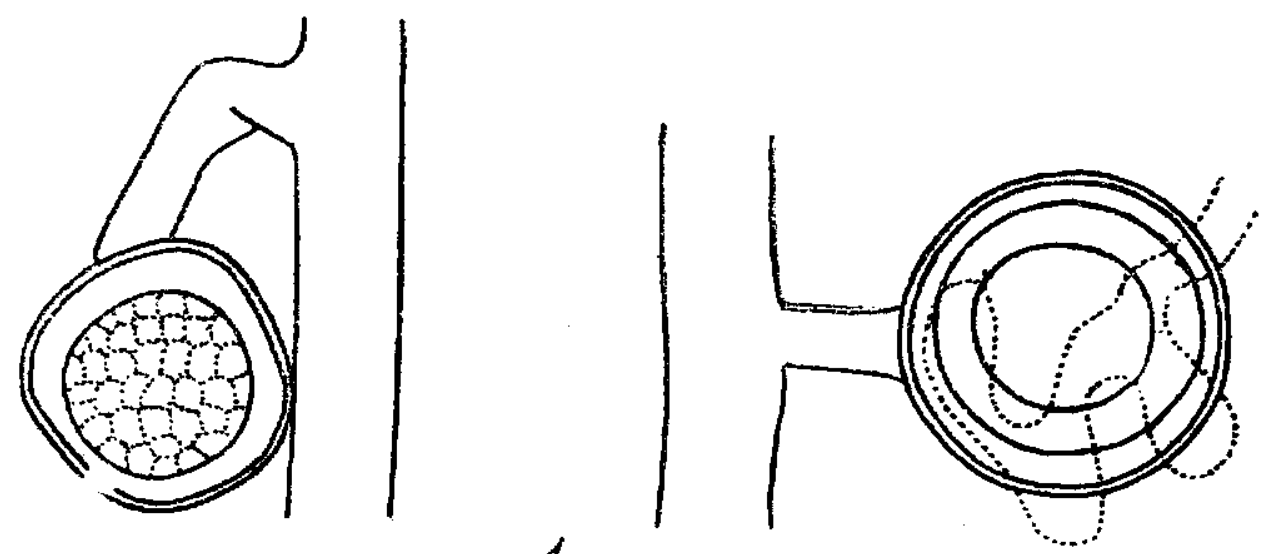

g

$20 N$ 
Est. VII

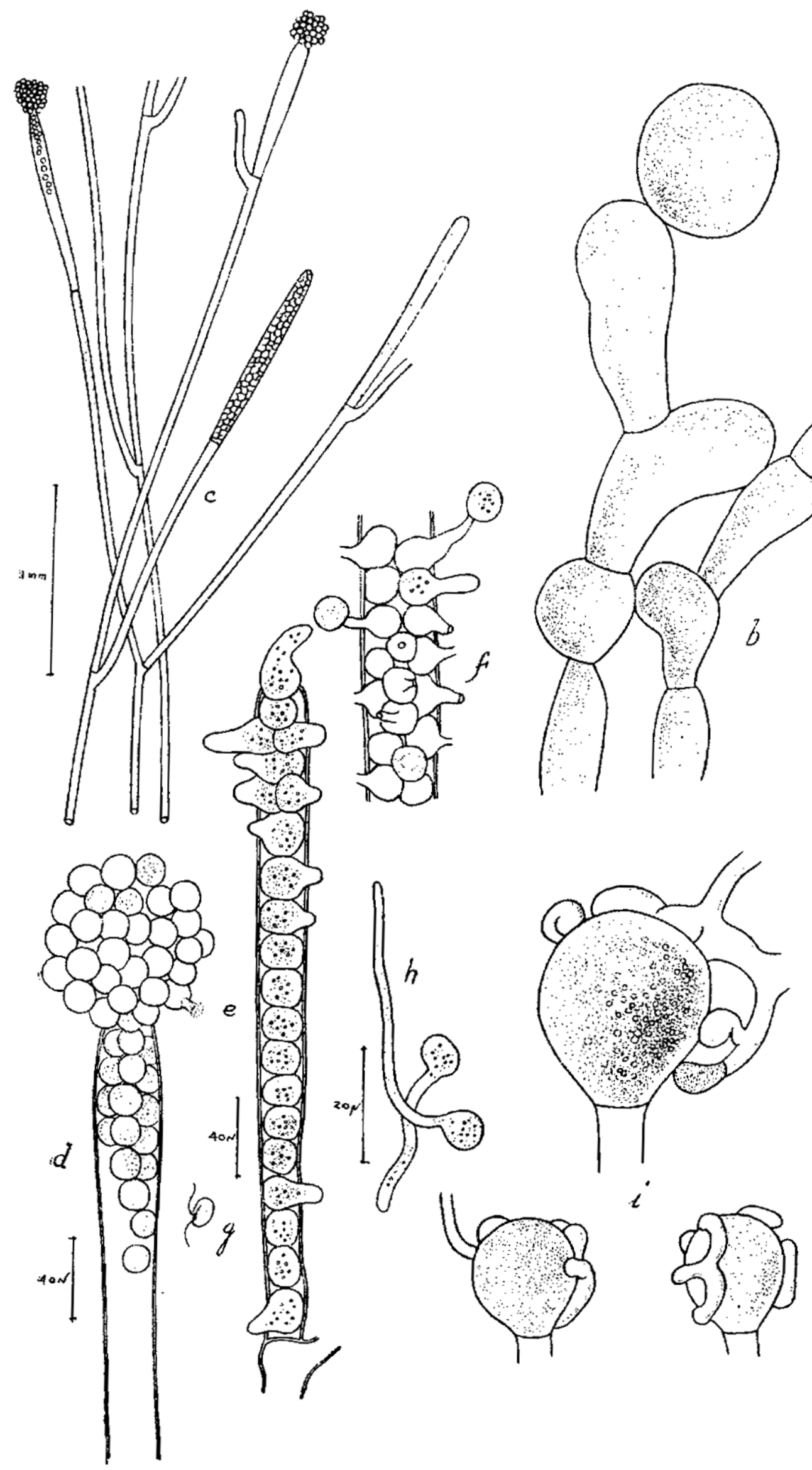


254

BR A G NT IA

VOL. III

Est. VIII

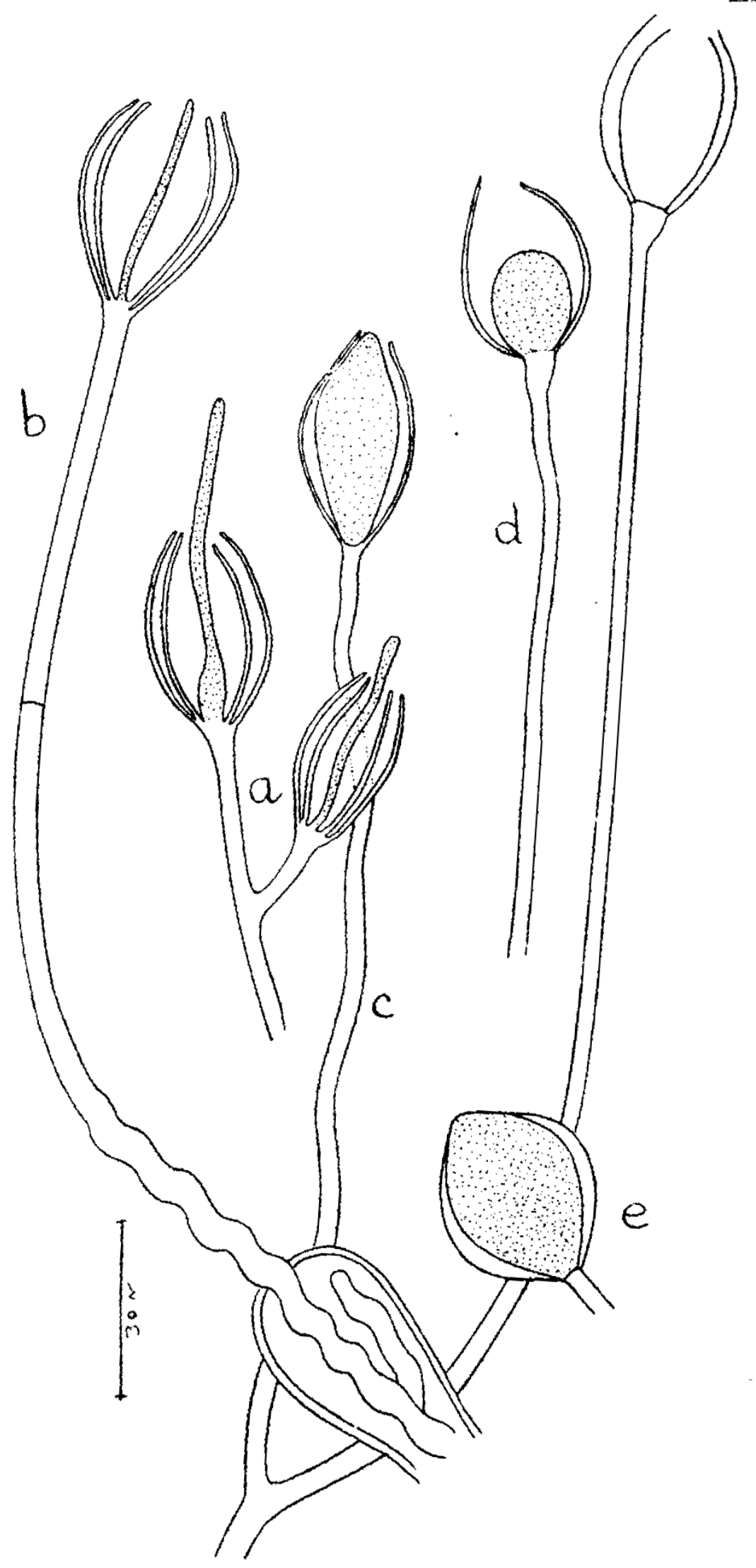




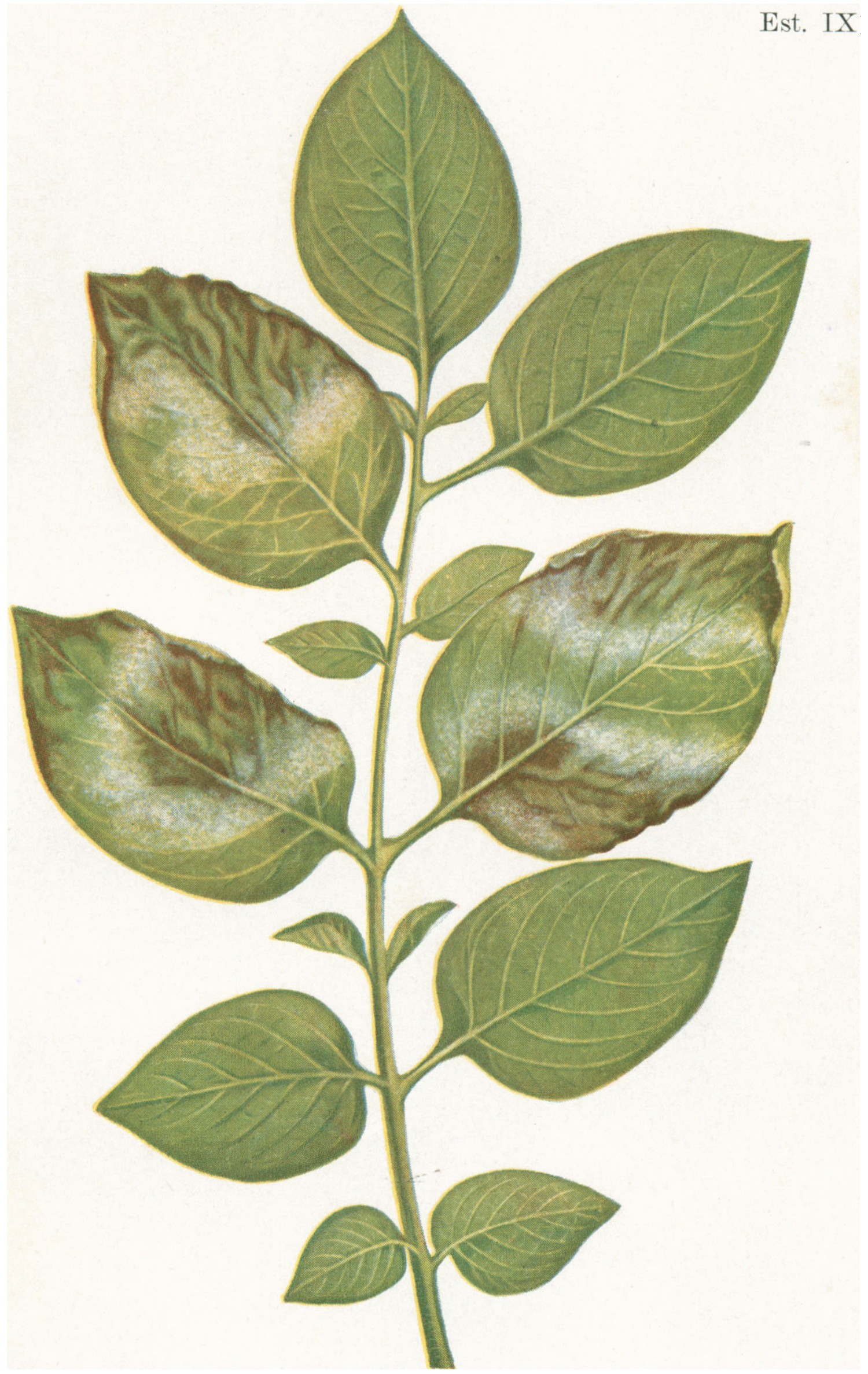


1943

BR A GA T IA

257

Est. X
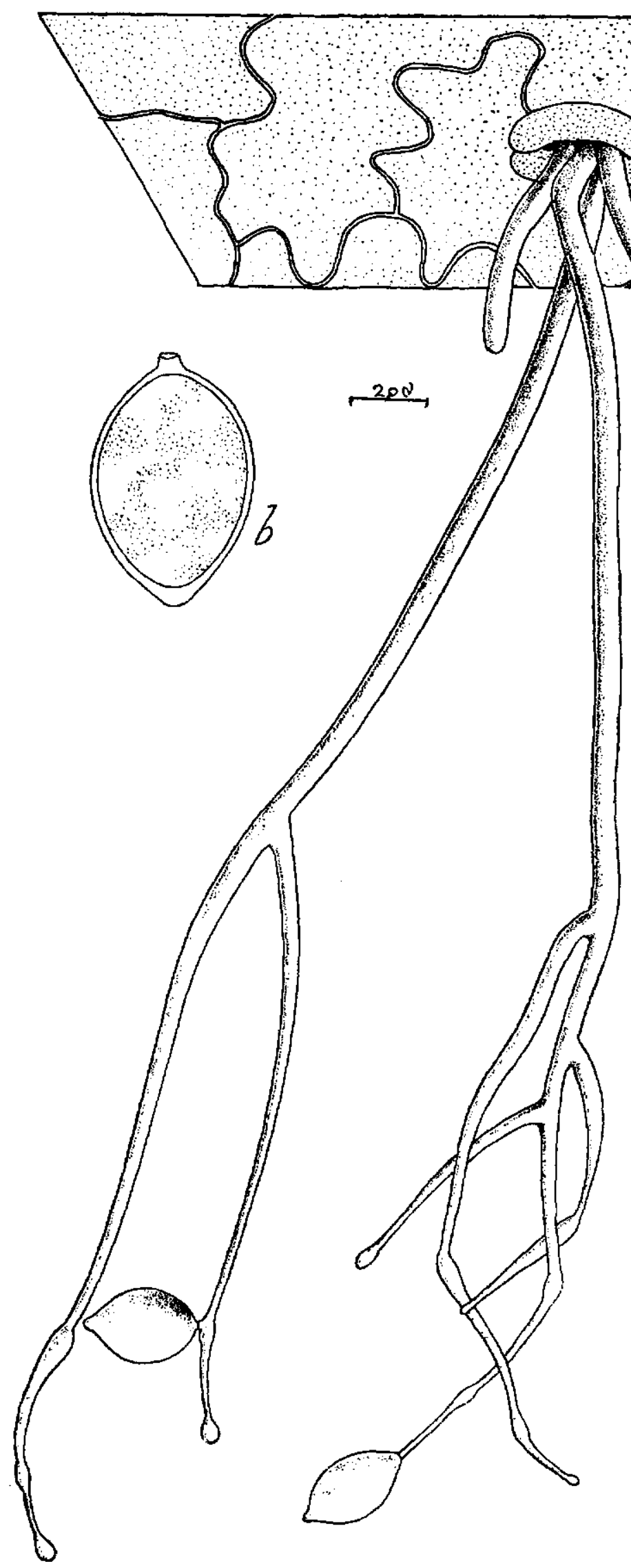


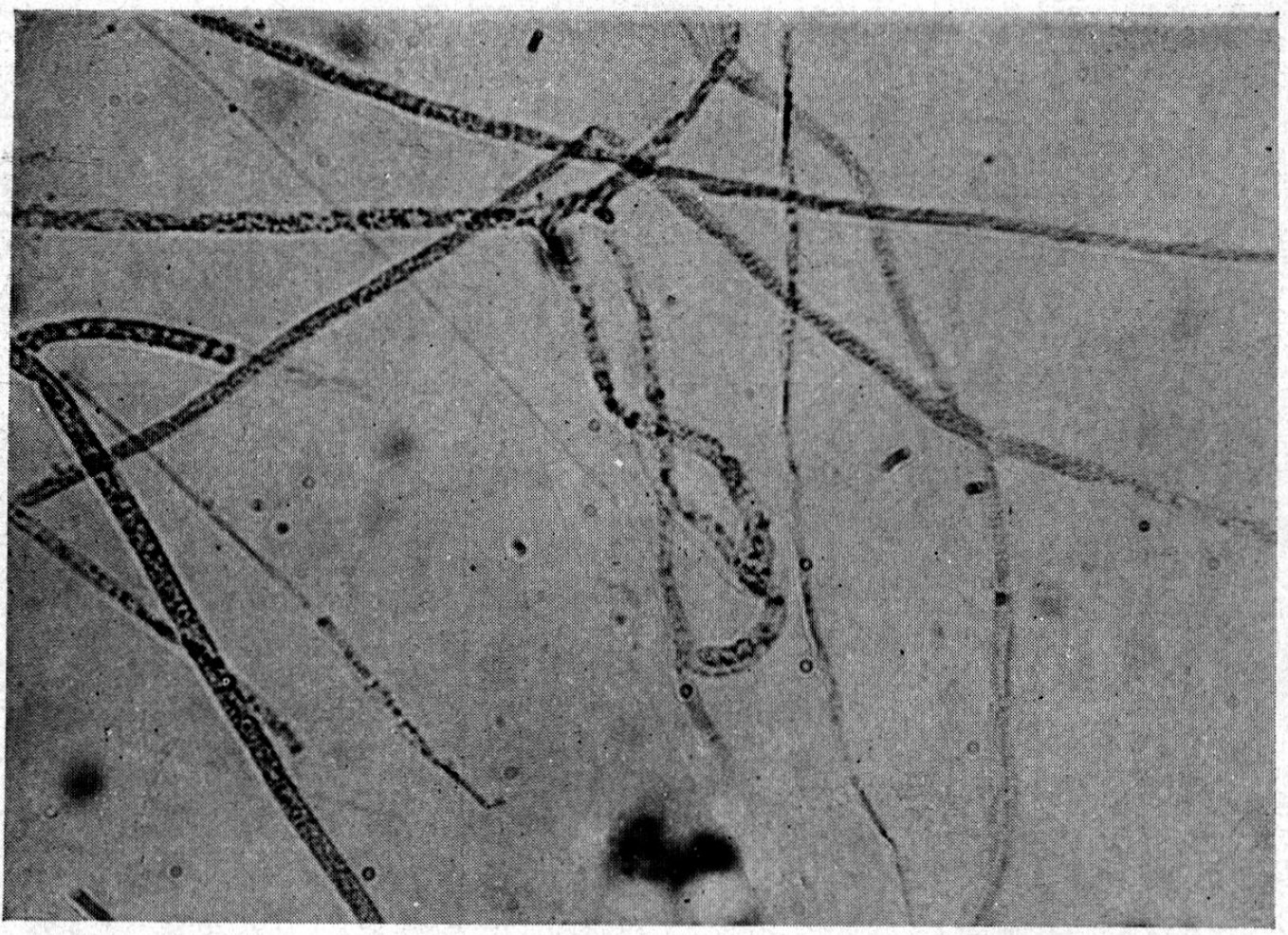

\section{a}

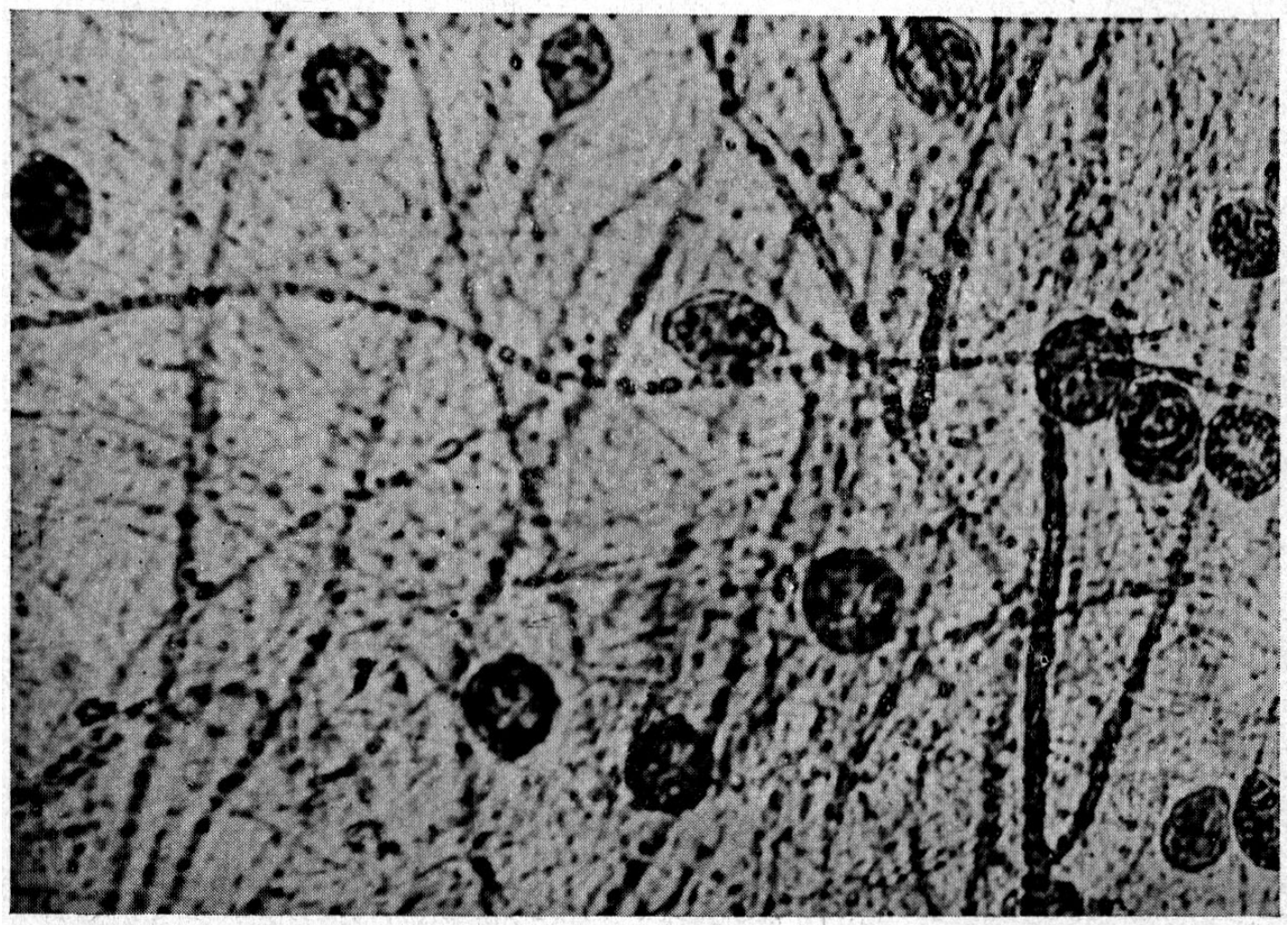


Est. XII

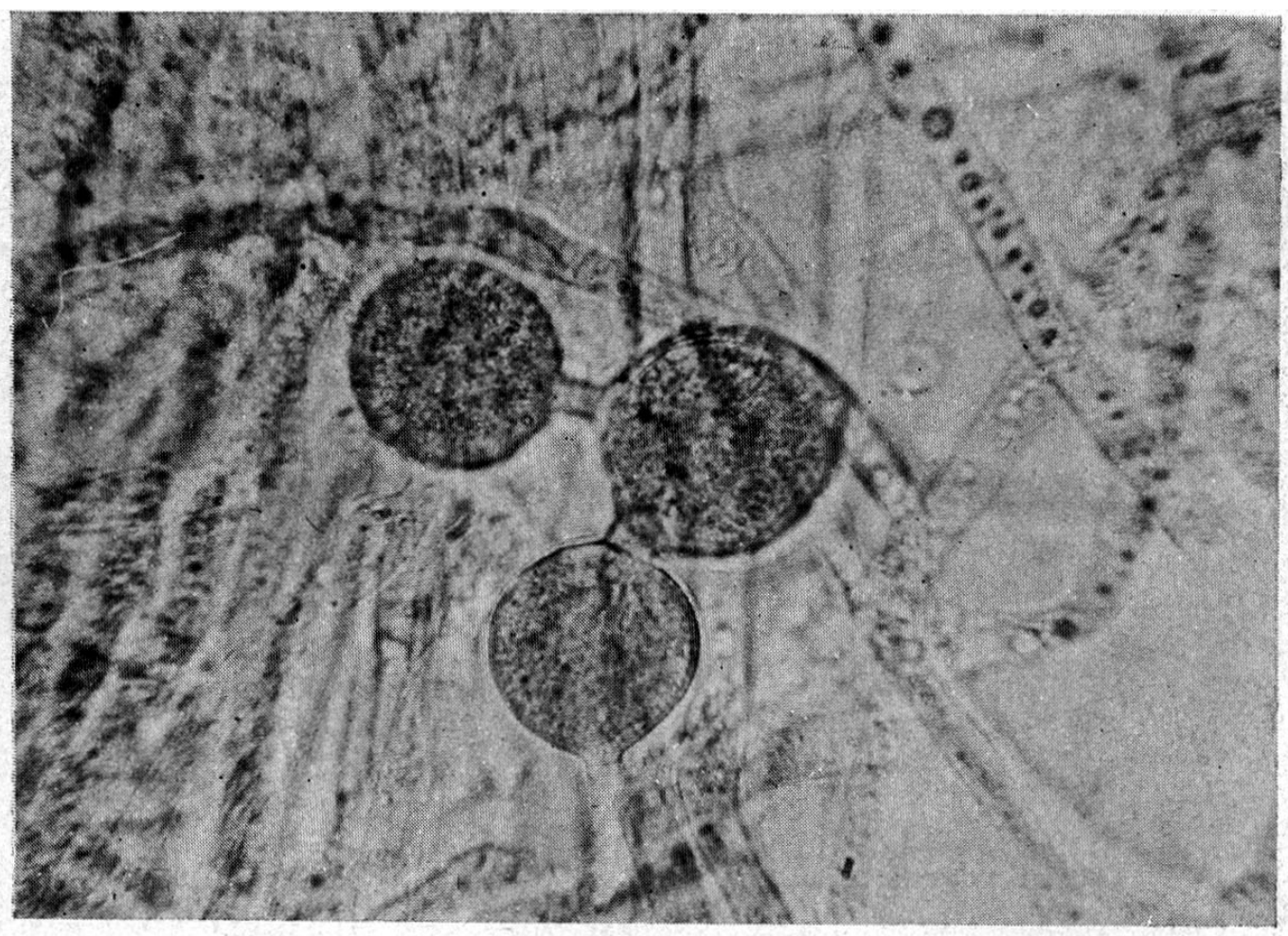

\section{c}

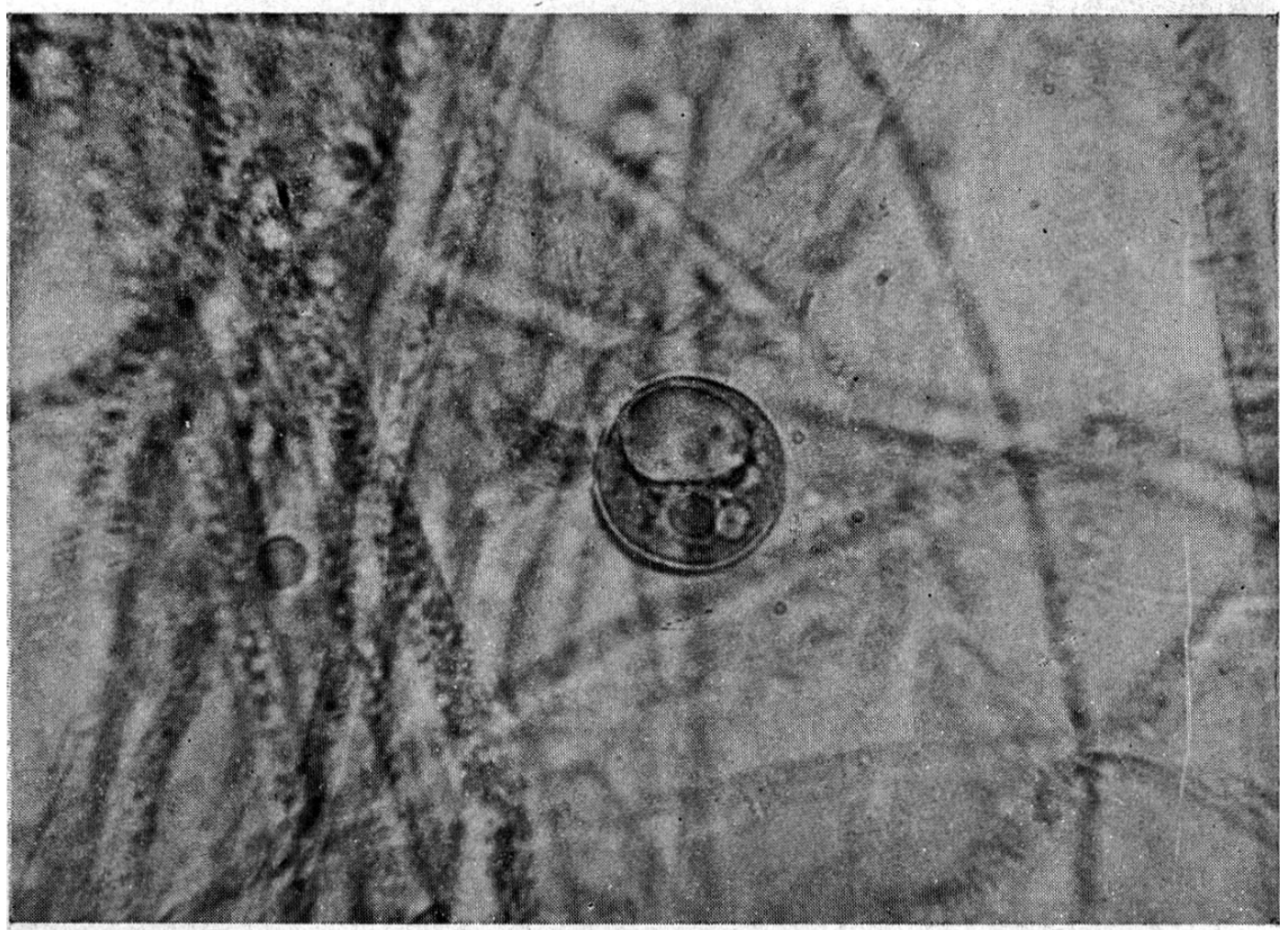


Est. XII I

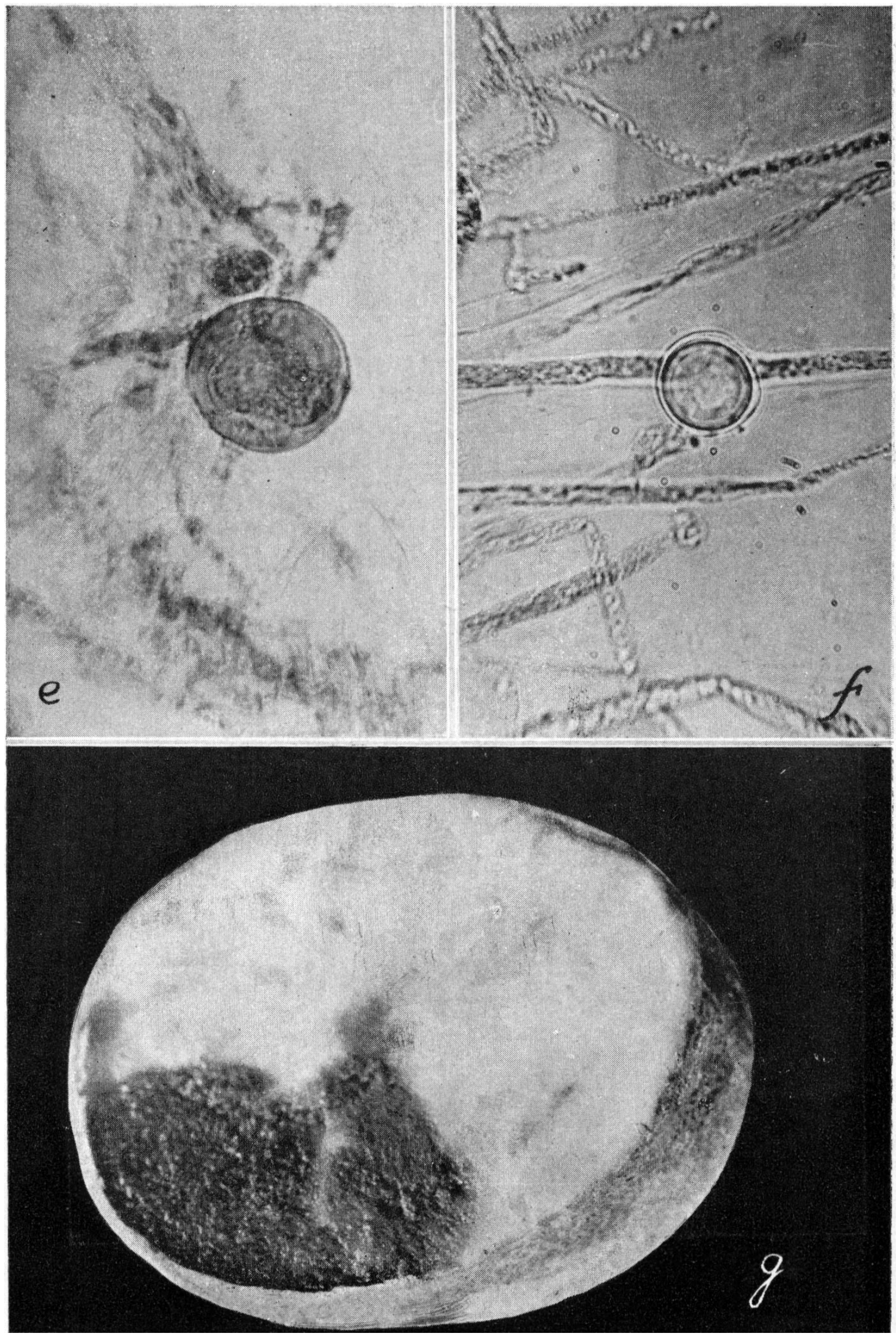


Est. XIV

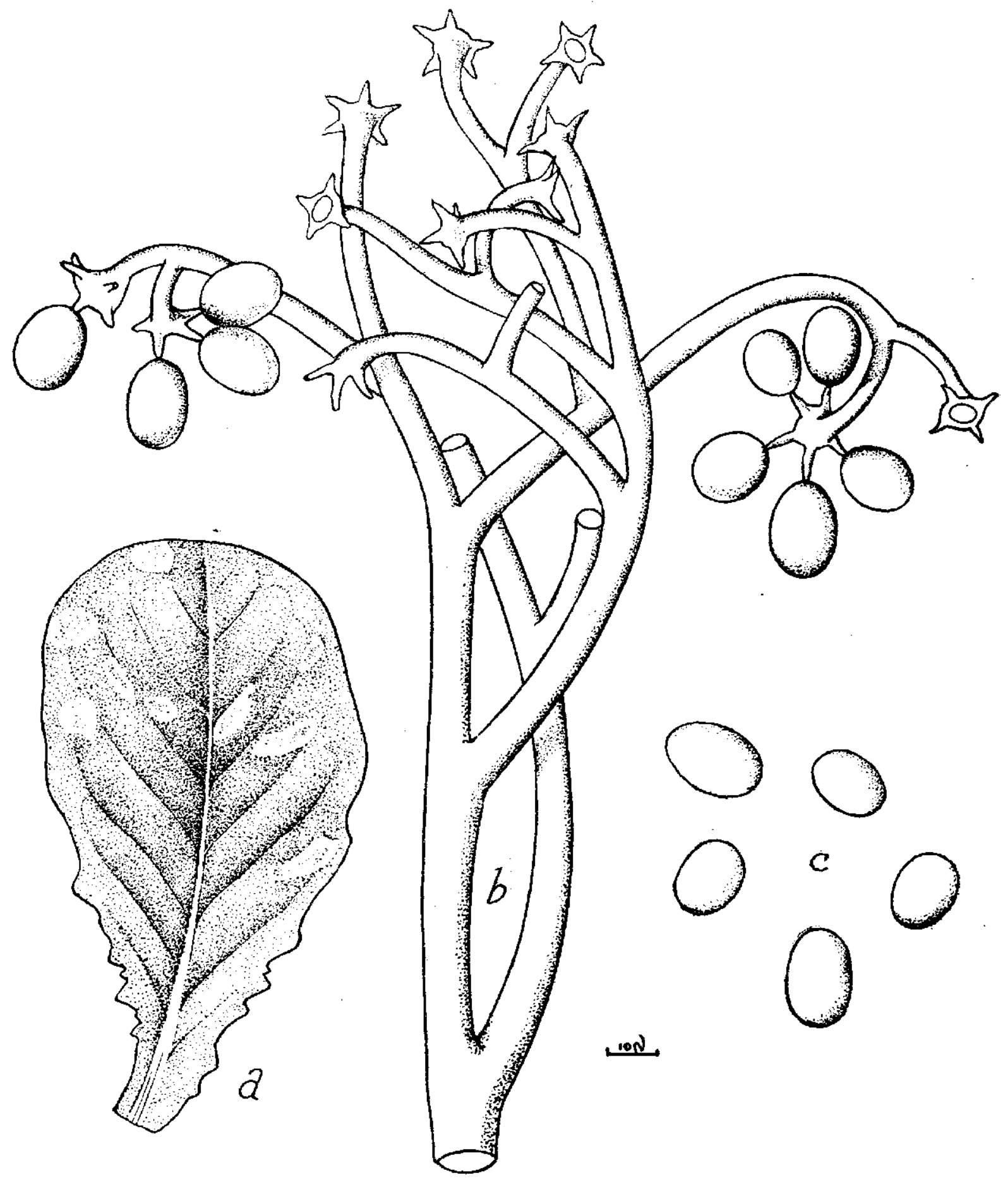




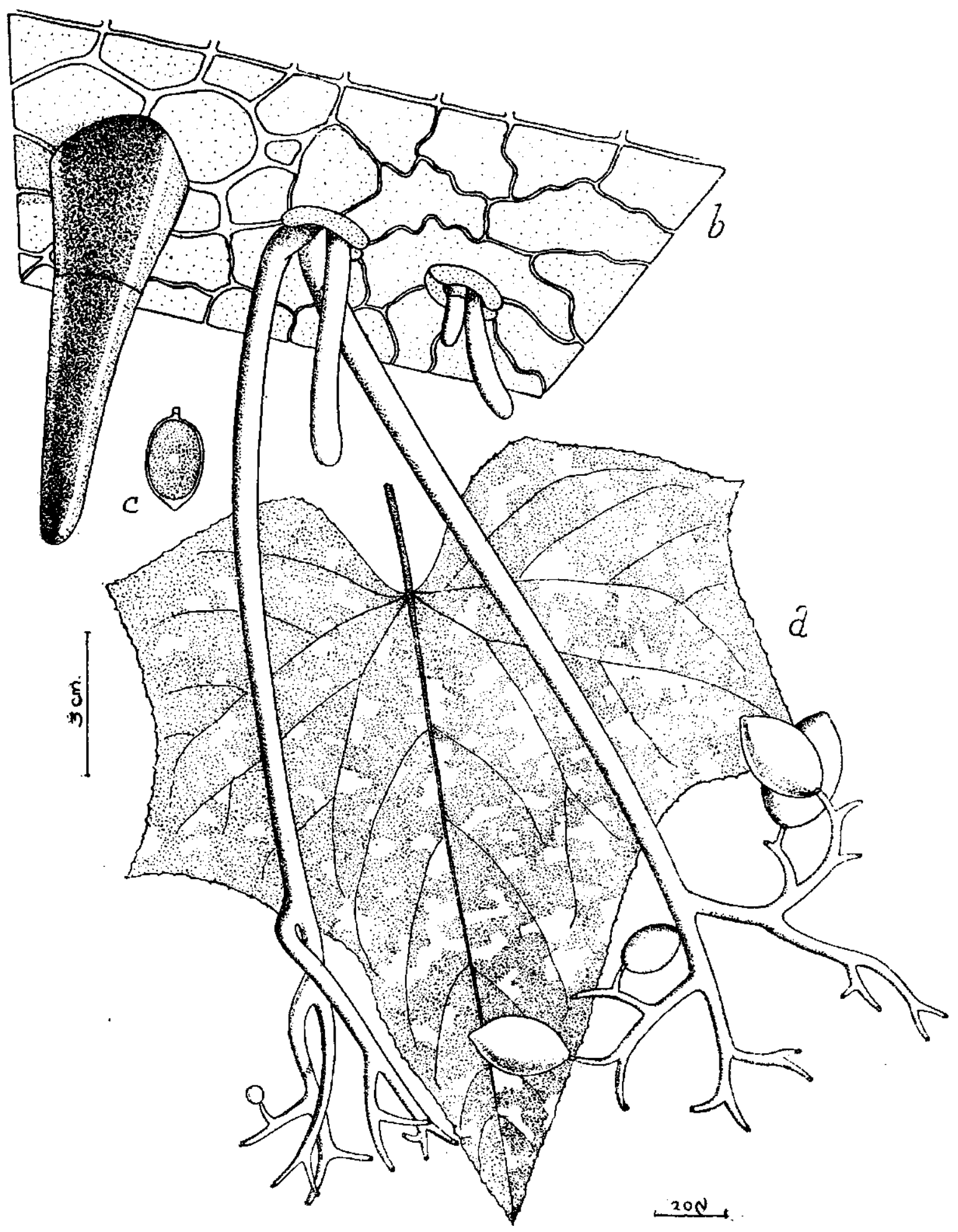


Est. XVI

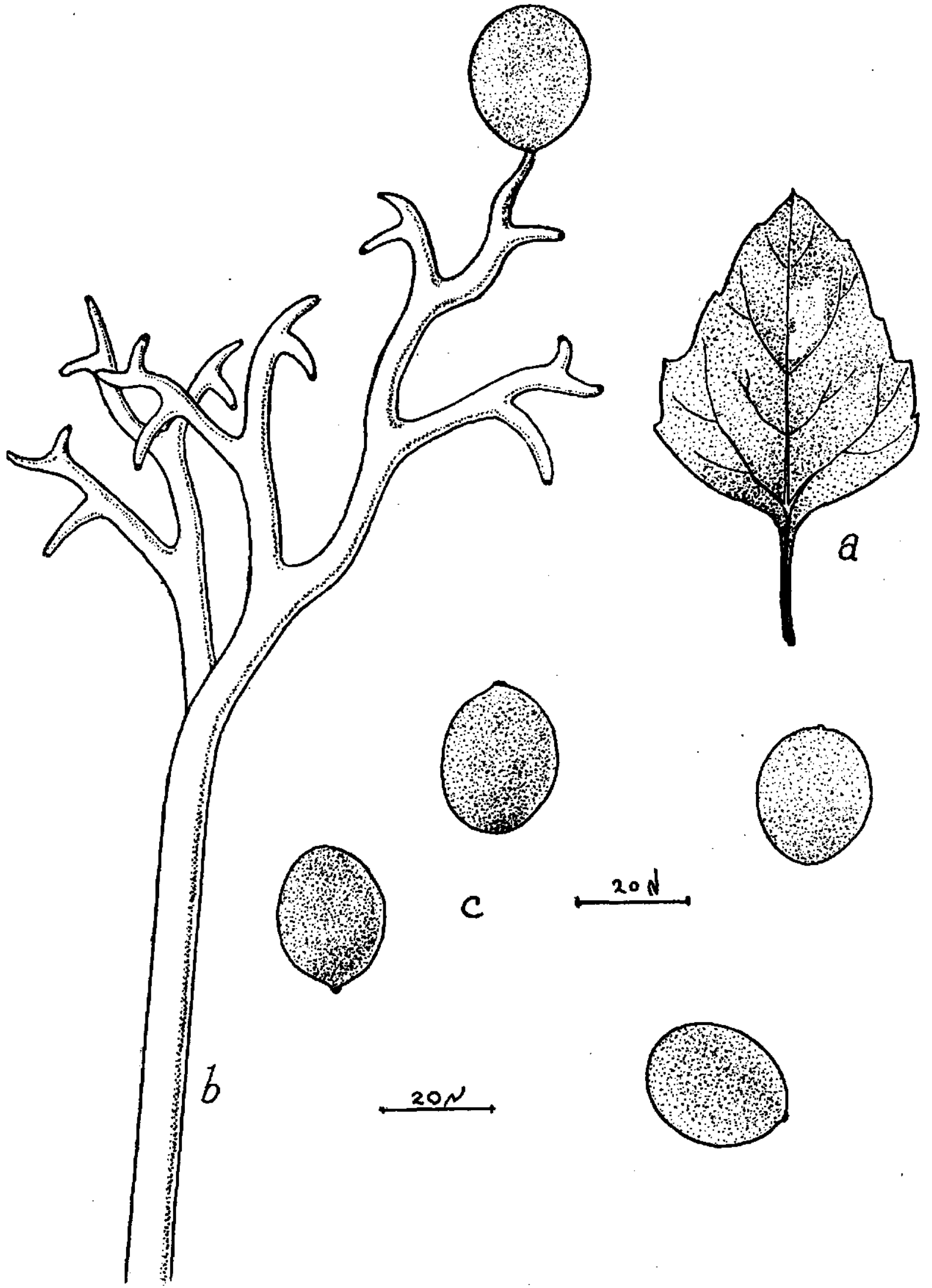


Est. XVII

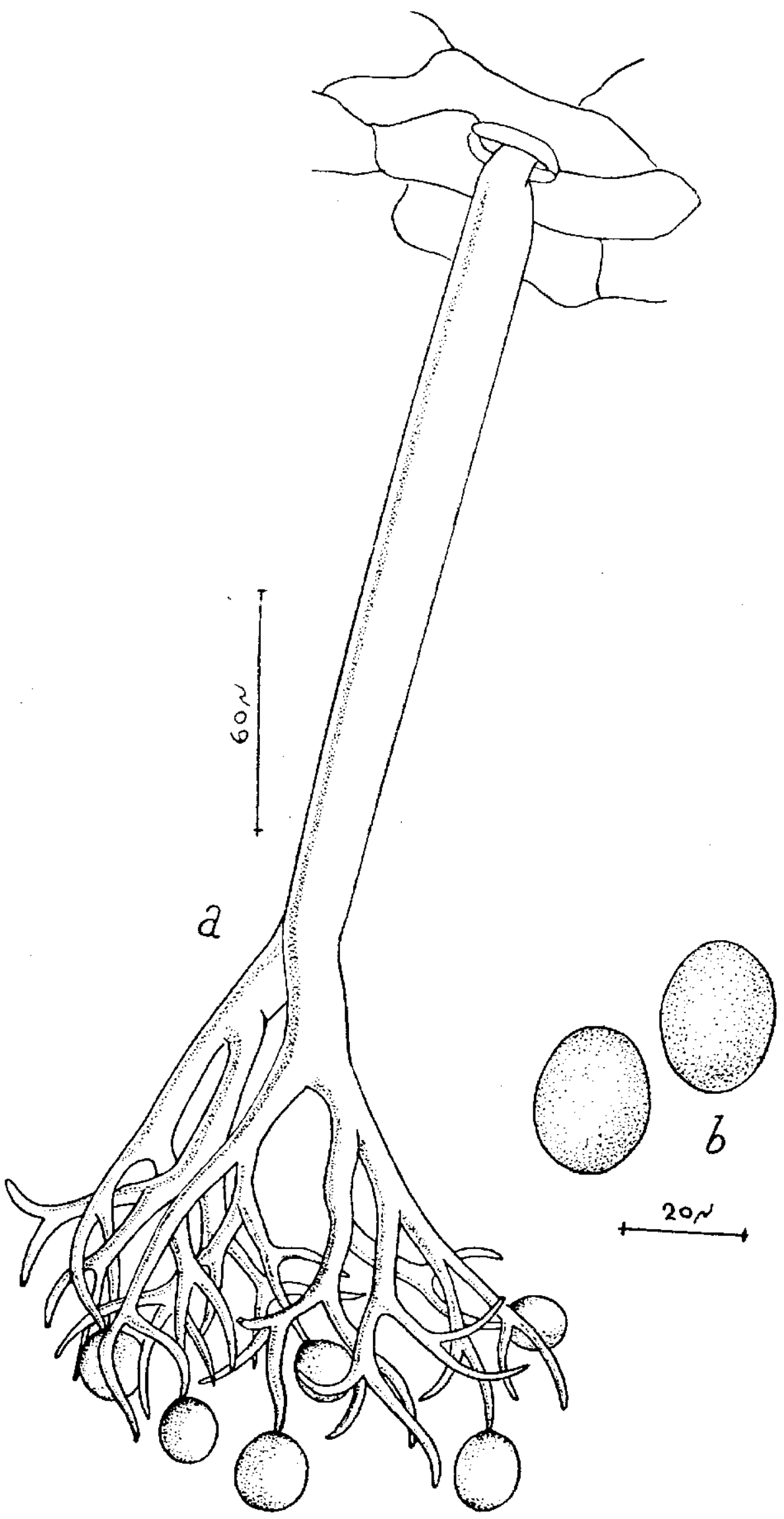


Est. XVIII

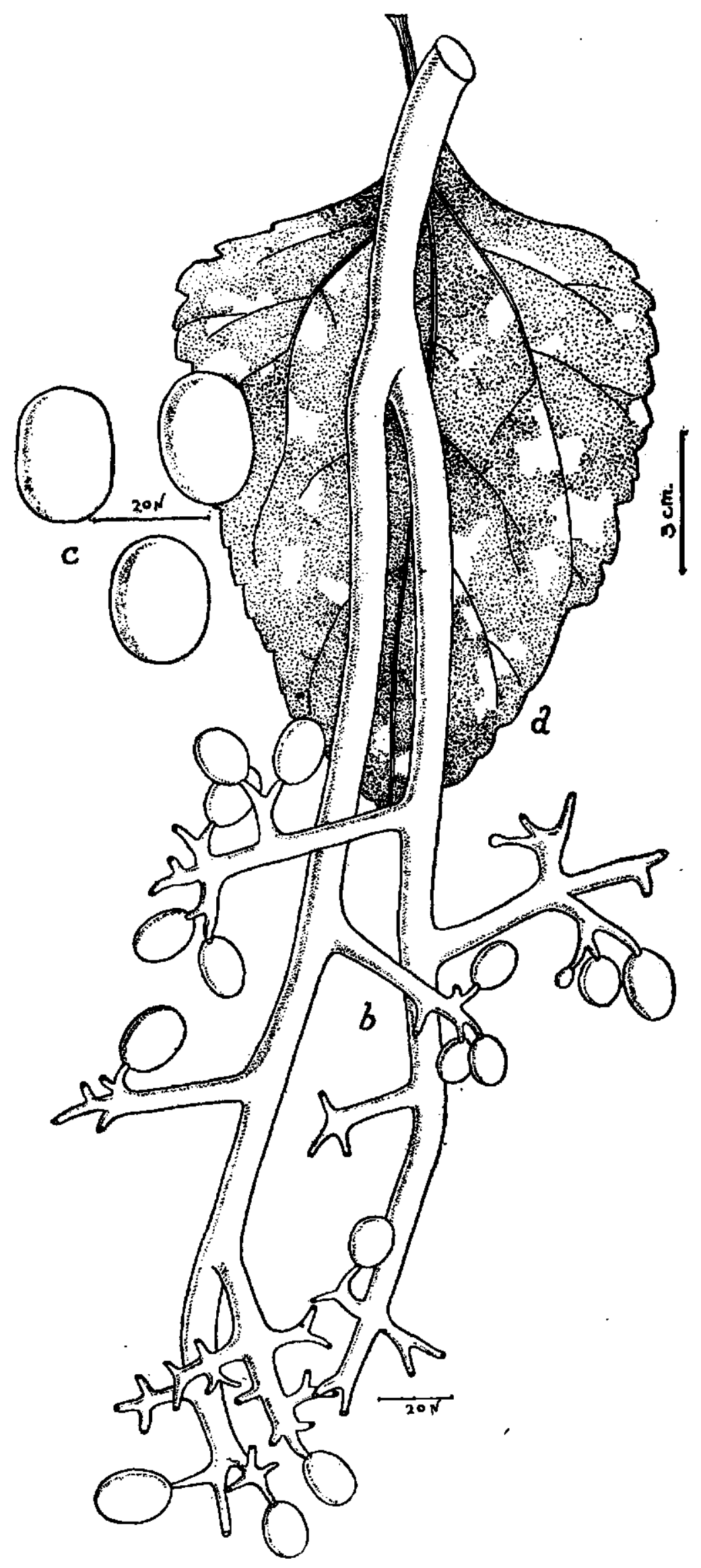




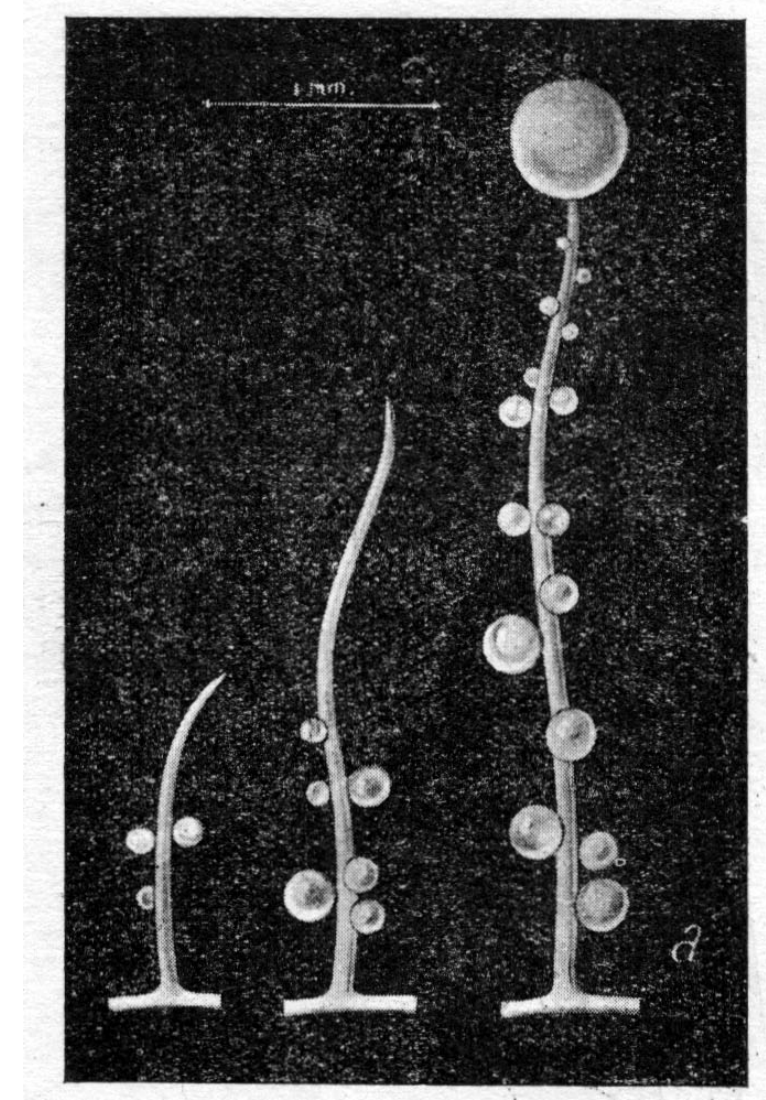

Est. XIX
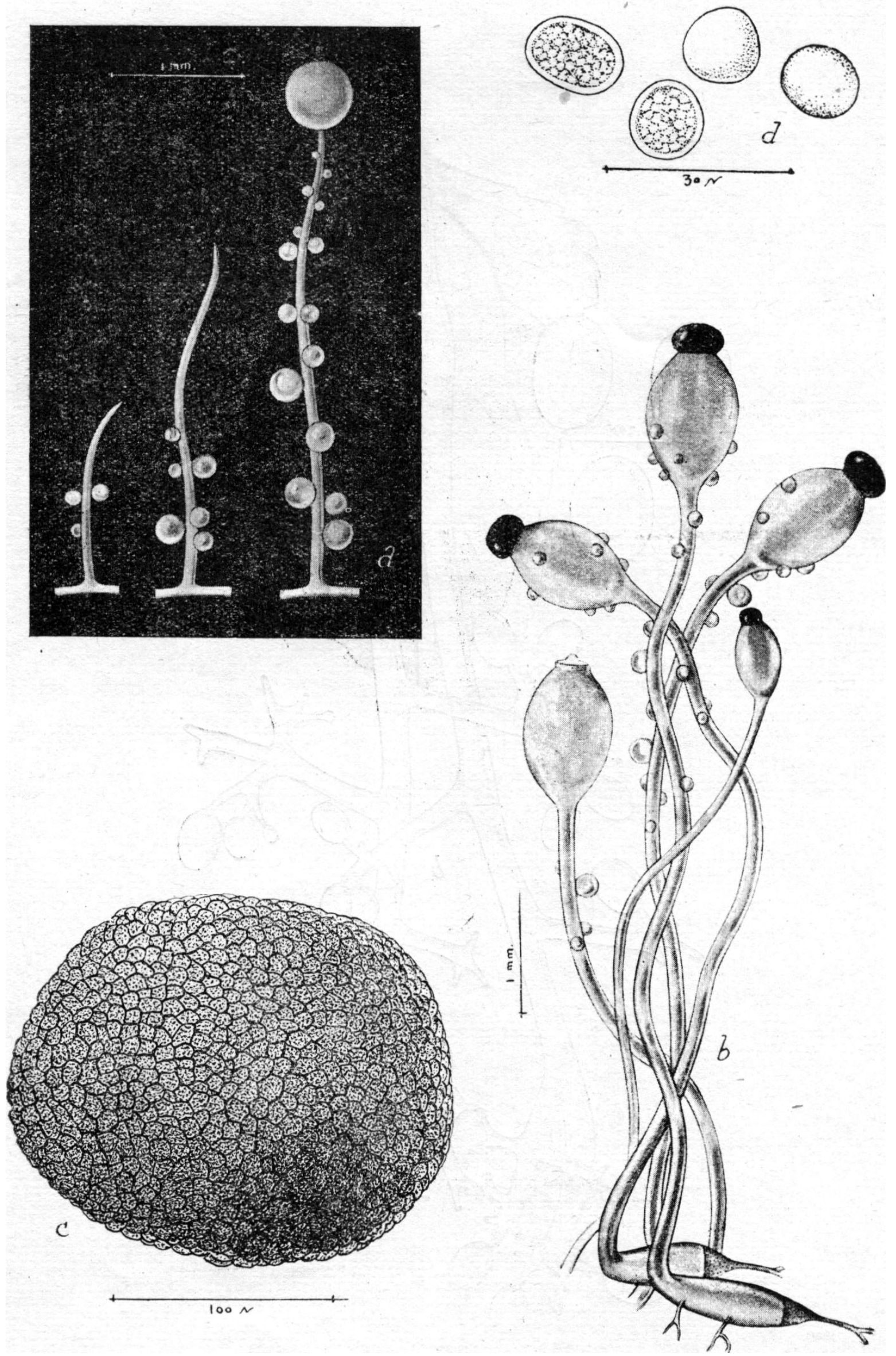
Est. XX

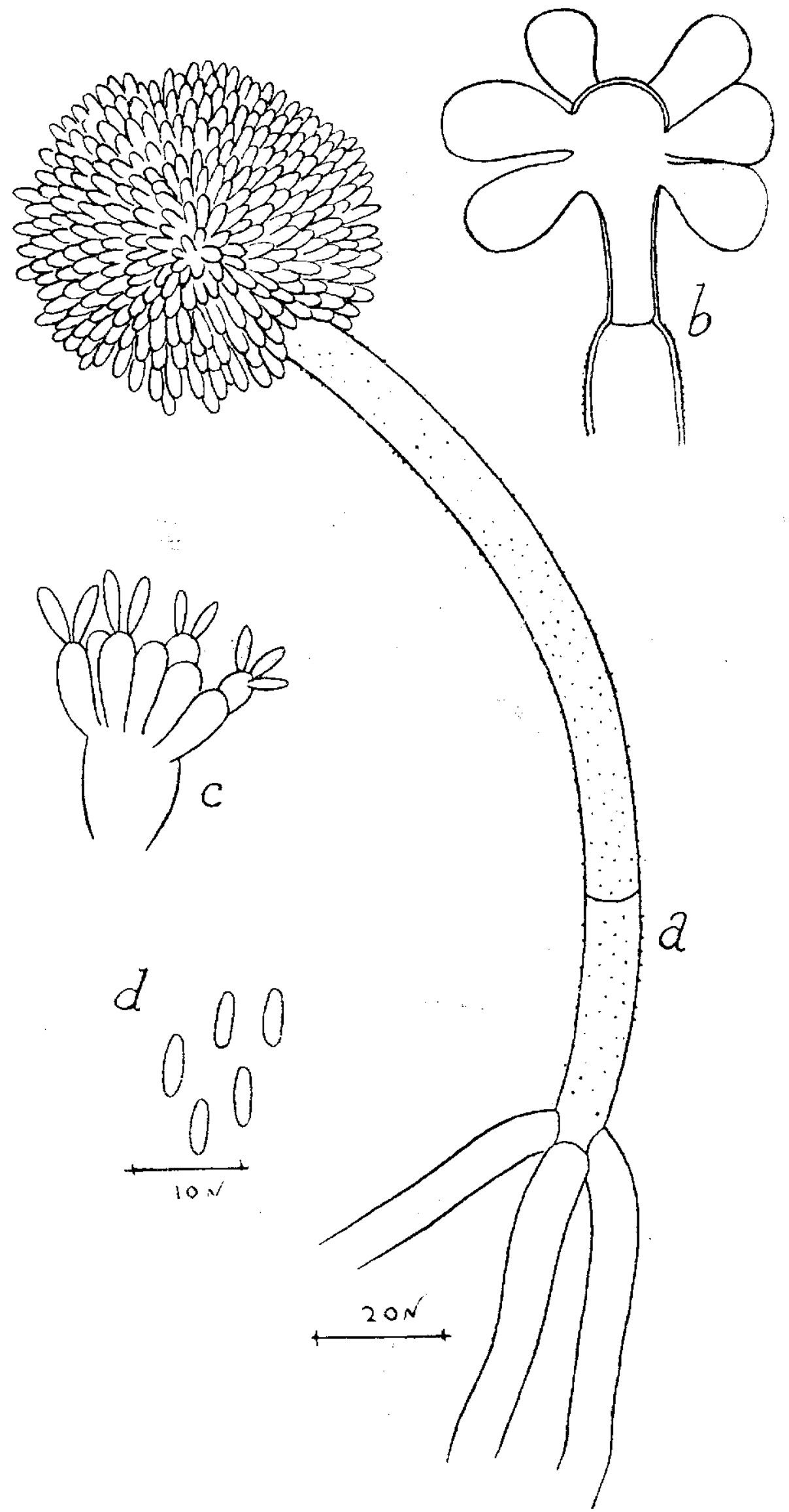



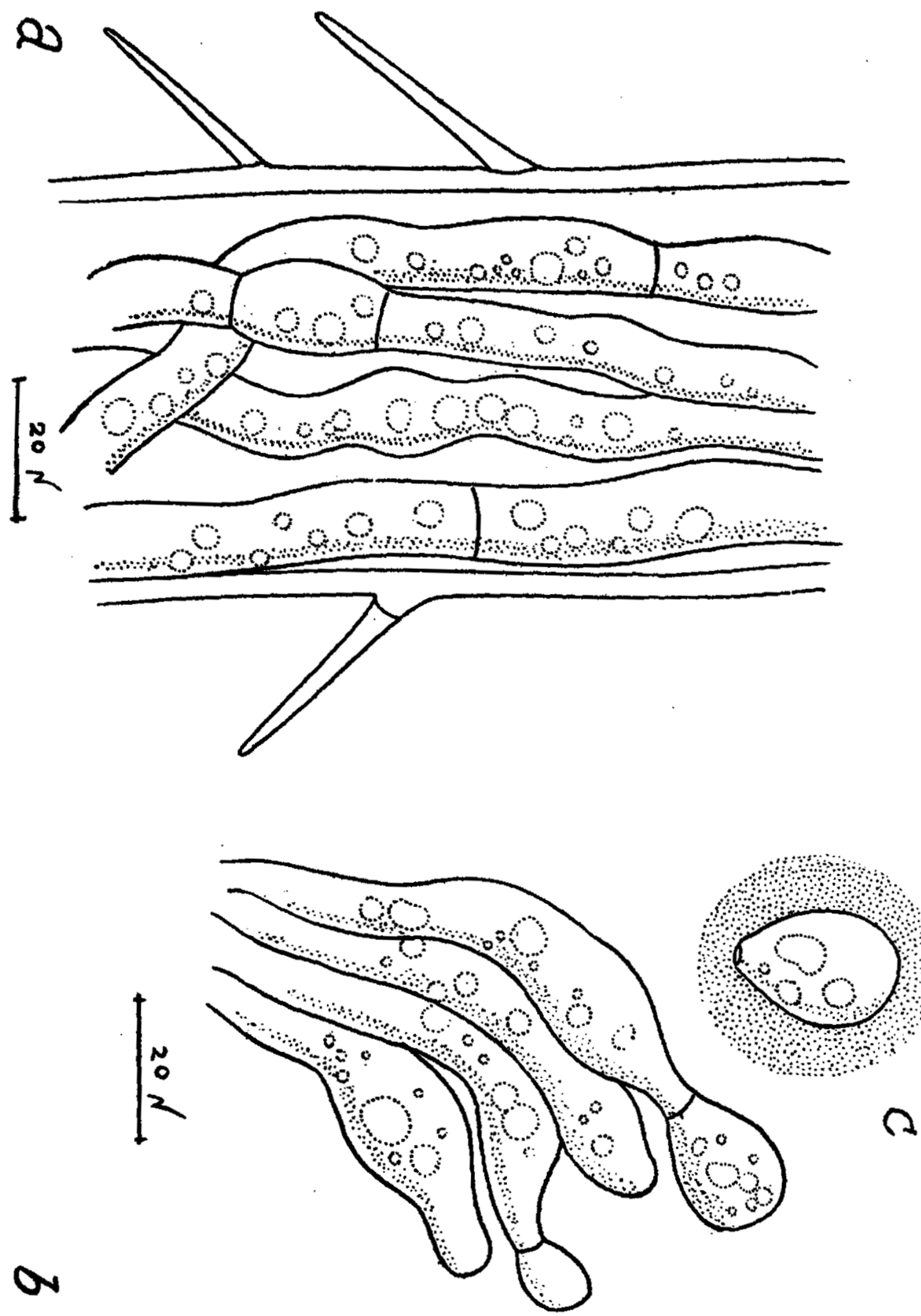
Est. XXII

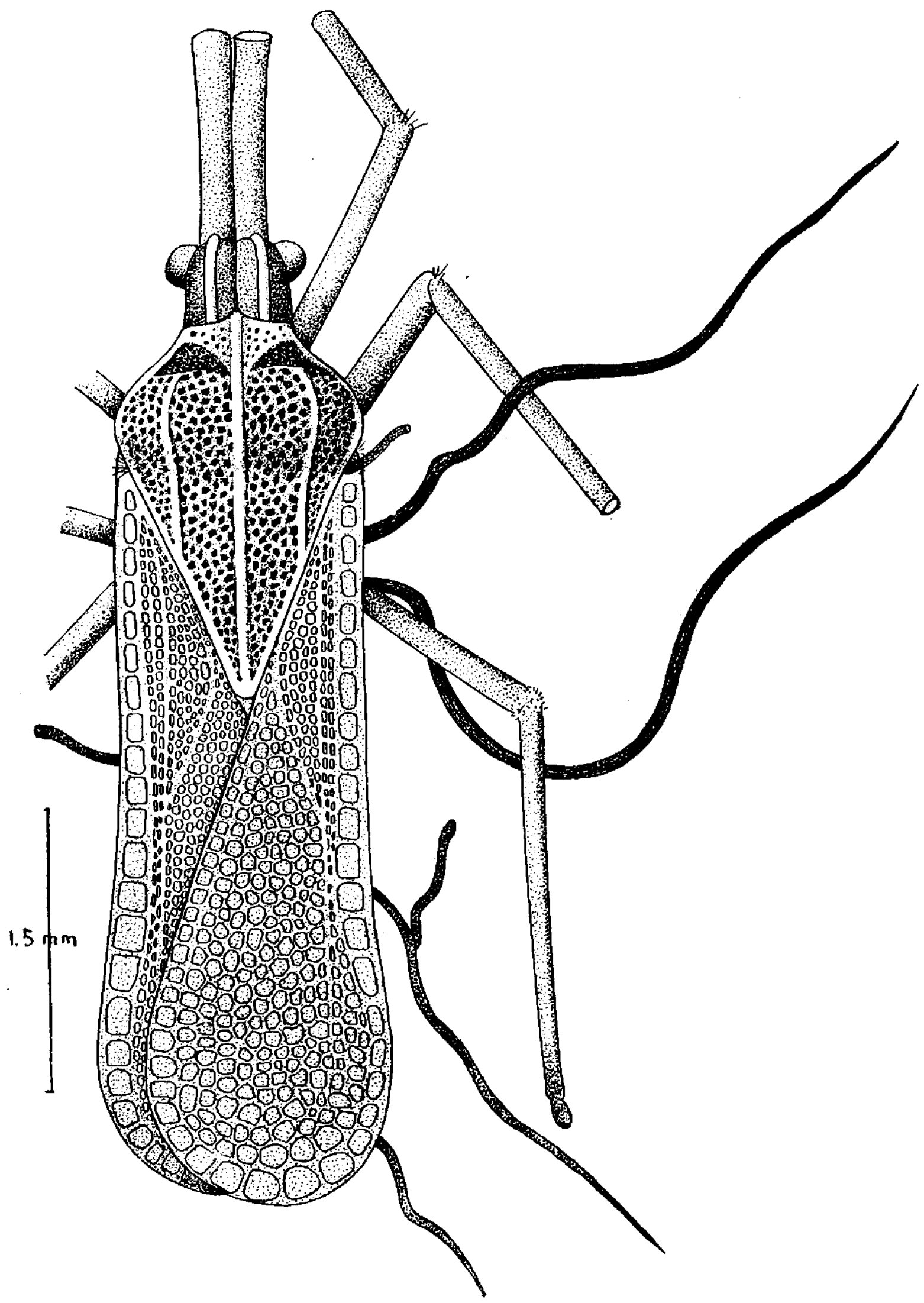

